\title{
The Anticancer Properties of Dietary Polyphenols and its Relation with Apoptosis
}

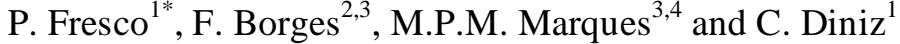

${ }^{I}$ REQUIMTE/FARMA, Serviço de Farmacologia, Faculdade de Farmácia, Universidade do Porto, Portugal; ${ }^{2}$ Laboratório de Química Orgânica, Faculdade de Farmácia, Universidade do Porto, Portugal; ${ }^{3}$ Unidade "Química-Física Molecular", Universidade de Coimbra, Portugal; ${ }^{4}$ Departmento de Bioquímica, Faculdade de Ciências e Tecnologia, Universidade de Coimbra, Portugal

\begin{abstract}
Aberrantly regulated apoptosis is involved in the pathogenesis of several diseases and defective apoptosis leads to uncontrolled cell proliferation and tumorigenesis. Cancer is an example of a pathologic condition where the normal mechanisms of cell cycle regulation are dysfunctional either by excessive cell proliferation, inhibited/suppressed apoptosis or both. Dietary habits are estimated to contribute to, at least, one third of all human cancers, showing that dietary components can exacerbate or interfere with carcinogenesis. However, several epidemiological studies have revealed that some dietary factors can decrease the risk of different types of cancer. Apoptosis is suggested to be a crucial mechanism for the chemopreventive properties associated with several dietary factors by eliminating potentially deleterious (damaged/mutated) cells. Food, a readily available item, contains several promising chemopreventive agents. Polyphenols are serious candidates since they are responsible for the cancer protective properties of a diet rich in vegetables and fruits: numerous phenolic compounds showed antiproliferative and cytotoxic effects and, more specifically, pro-apoptotic activities, in several cancer cells lines and animal tumor models. The aim of the present review is to analyze and summarize several aspects related to the molecular mechanisms of apoptosis induced by dietary factors with particular emphasis on polyphenols. Dietary factors that can activate cell death signals and induce apoptosis, preferentially in precancerous or malignant cells, and the study of their apoptotic inducing targets can represent a mean to devise new strategies for cancer prevention in the future.
\end{abstract}

Keywords: Apoptosis, cancer, chemoprevention, diet, polyphenolic compunds.

\section{INTRODUCTION}

With more than 10 million new cases each year, cancer is, at present, one of the most devastating diseases worldwide with an immense disease burden not only for affected individuals, their relatives and friends but also representing heavy challenges to health care systems [1]. In the year 2000, cancer was responsible for $12 \%$ of the nearly 56 million deaths worldwide and in many countries this percentage is even higher with more than a quarter of deaths attributable to cancer. Moreover, it is expected that cancer rates can further increase by $50 \%$ to 15 million new cases in the year 2020, mainly due to steadily ageing populations in both developed and developing countries.

The World Cancer Report also reveals areas where action by governments and health practitioners could stem this trend, and prevent as many as one third of cancers worldwide. Examples of areas where action can make a difference to stem the increase of cancer rates and prevent new cases (requiring the coordinated involvement of governments, community health organizations, health care professionals and individuals) are i) reduction of tobacco consumption, ii) early detection through screening and iii) implementation of nutrition (high intake of fruits and vegetables) and physical activity goals through population-based interventions [1].

Dietary habits are increasingly recognized as closely related with the development/maintenance or, by opposition, prevention of chronic diseases such as cancer, coronary heart disease, stroke or diabetes $[2,3]$.

Some dietary factors have been convincingly identified to increase cancer risk: excess alcohol consumption (more than 2 units a day), some forms of salting and fermenting fish, consumption of very hot drinks and food or aflatoxins (fungal contaminants found on foods such as grains or nuts). By opposition, accumulating evidence suggests that several other dietary habits are related with a

*Address correspondence to this author at the Laboratório de Farmacologia, Faculdade de Farmácia, Universidade do Porto, Rua Aníbal Cunha, 164, 4050-047 Porto; Tel: +351 22 2078970; Fax: +351 22 2078969;

E-mail: pfresco@ff.up.pt putative cancer risk decrease: consumption of fruit and vegetables, fish, omega-3 fatty acids, carotenoids, vitamins B2, B6, folate, B12, $\mathrm{C}, \mathrm{D}, \mathrm{E}$, calcium, zinc, selenium and non-nutrient plant constituents such as polyphenols. Several epidemiological studies have been carried out showing that intake of fruits and vegetables [4,5], polyunsaturated fats (rich in omega-3 fatty acids) [6-8] and fibers $[9,10]$ has been used successfully in the prevention of diseases associated with oxidative stress conditions, namely cancer. Furthermore, these studies had led to the establishment of a relation between fruit and vegetable consumption and a reduction of risk of cancer and cardiovascular diseases. A correlation between daily intake of fruits or vegetables and a $4 \%$ risk reduction for coronary heart disease [11], a reduction of stroke risk [12] and protection against several types of cancer such as lung, colon and breast cancer [13], oral cancer [14] and bladder cancer [15] was found. Other studies suggested that reduction of meat consumption can represent an important approach to reduce the incidence of kidney cancer [16]; dietary fiber intake is inversely associated with risk of colorectal cancer [10], low fat intake may help in the prevention of bladder cancer [17]; a diet rich in linoleic acid and $\beta$-carotene has been inversely related with hepatocellular carcinoma [18] and high consumption of selenium has been associated with a reduced prevalence of colorectal adenomas [19]. In fact, several compounds found in human diet are increasingly viewed as having a crucial role in the prevention of cancer: compounds such as carotenoids, fatty acids, heterocyclic amines, vitamin $\mathrm{C}$ and $\mathrm{D}$, boron and selenium, fruits and vegetables were reported to contribute to the preventing properties ascribed to diet [20,21]. This implies that many cancers may be prevented by changes in dietary habits.

The fruit and vegetable cancer preventing properties have been ascribed, at least in part, to their high content in polyphenols [22] Polyphenols are integral part of the human diet with flavonoids and phenolic acids representing the majority of polyphenols present in food. In addition to fruits and vegetables, leaves, nuts, seeds, barks and flowers are also rich sources of polyphenols [22,23].

In the last decade, numerous laboratory studies, using both cancer cell lines and several animal tumor models, unequivocally showed that polyphenols have cancer-preventing activities and have been considered as promising chemopreventive agents [23-25]. 
These compounds can influence important cellular and molecular mechanisms related to carcinogenesis such as inhibition of key proteins in signal transduction pathways (such as MAP-kinases or AP-1), inhibition of the transcription factor NF- $\kappa \mathrm{B}$ and related activities, modulation of cell-cycle regulation or induction of apoptosis [25], affecting cell differentiation, proliferation and apoptosis, imune response and chemical metabolism [22].

Apoptosis, a regulated form of cell death, is a complex process involving active participation of affected cells in a self-destruction cascade and, in addition to its importance as a biological phenomenon, defective apoptotic processes have been implicated in an extensive variety of diseases: excessive apoptosis causes hypotrophy involved in pathologies such as in myocardial infarction, atherosclerose or Parkinson's disease, whereas inhibition of apoptosis leads to uncontrolled cell proliferation, resulting in events related to autoimmune disorders and cancer [20,26]. Apoptosis is conceivably the most potent defense against cancer since it is the mechanism used for metazoans to eliminate deleterious cells. Furthermore, growing evidence suggests that a large number of chemopreventive agents can induce apoptosis in transformed cells both in vitro and in vivo, which appears to be associated with their effectiveness in modulating the carcinogenesis process [27]. Since apoptosis provides a physiologic mechanism for eliminating abnormal cells, dietary factors affecting apoptosis can present important effects on carcinogenesis. Conceivably, activation of apoptosis in pre-cancerous cells offers a prevention mechanism of cancer (chemoprevention) by dietary factors [28].

\section{APOPTOSIS}

The term apoptosis was first used in 1972 [29] to describe a morphological distinct form of cell death, although certain components of the concept have only recently explicitly described. This process of programmed cell death is characterized by distinct morphological characteristics and energy-dependent biochemical mechanisms. Apoptotic cells show morphological changes such as cell shrinkage, pyknosis and extensive plasma membrane blebbing with the formation of apoptotic bodies. Apoptotic bodies are subsequently phagocytosed by macrophages, parenchymal or neoplastic cells. Apoptosis hardly causes any inflammatory response because i) apoptotic cells do not release their constituents into the surrounding intersticial tissue; ii) apoptotic cells are quickly phagocytosed by surrounding, preventing secondary necrosis and iii) the engulfing cells do not produce inflammatory cytokines [30]. Expression and activation of tissue transglutaminase leads to extensive protein cross-linking, DNA breakdown (occurring by activation of $\mathrm{Ca}^{2+}$ and $\mathrm{Mg}^{2+}$ dependent DNases) and the phagocytic recognition seems to result both from movement of normally inward facing phophatidylserine and the exposure of Annexin I and calreticulin to the outer layer, representing signals for phagocytic recognition of apoptotic cells [31].

In contrast, the alternative to apoptotic cell death, necrosis is considered as a toxic process which follows an energy-independent mode of cell death with different morphological characteristics such as cell swelling, formation of vacuoles, distended endoplasmic reticulum (ER), altered mitochondria, rupture of cell organelles and eventually, of cell membrane [32]. When this happens, cytoplasmic content is released into surrounding tissues sending chemotatic signals with eventual recruitment of inflammatory cells.

Apoptosis can be initiated upon receiving extracellular or intracellular signals, including growth factor withdrawal, UV- or $\gamma$ irradiation, chemotherapeutic agents, heat shock, nutrient deprivation, or by a family of transmembrane proteins called death receptors (DR). These signals are transduced to adapter proteins and transmitted to specific cysteine proteases called "initiator caspases". At this point the cell is committed to undergo apoptosis, followed by "execution of cells" (mediated by sequential activation of the so called "executioner caspases", systematic disintegration of cell structure and phagocytosis of the cell corpses [20,31]).

Caspases (cysteine-dependent aspartate-specific proteases) are typically activated in the early stages of apoptosis. This family of proteins is synthesized as inactive zymogens but, once activated, can begin a proteolytic cascade with resultant cleavage of key cellular components required for normal cellular function, including structural proteins in the cytoskeleton and nuclear proteins such as DNA repair enzymes. Caspases can also activate other degradative enzymes such as DNAases, which begin to cleave the DNA in the nucleus. So far, 14 different members of the caspase-family have been described in mammals [31,33,34]. The ten major pro-apoptotic caspases can be classified as initiators (caspase-2, -8, -9, -10), effectors or executioners (caspase-3, $-6,-7)$ and inflammatory caspases (caspase-1, -4, -5) [31,35]. Other caspases identified to date, caspase-11, -12, -13 and -14, are involved in specific apoptotic processes or are expressed solely in specific types of tissues [31].

It is currently accepted that apoptosis can occur through two major complex and energy-dependent apoptotic pathways, the extrinsic (or death receptor) pathway and the intrinsic (or mitochondrial) pathway, as depicted in Fig. (1). Another pathway has also been described, the perforin-granzyme pathway. The perforingranzyme pathway can induce apoptosis either via granzyme B, sharing the same executioner pathway of the extrinsic and intrinsic pathways (caspase activation), or granzyme A, activating a parallel, caspase-independent cell death pathway by single stranded DNA damage [34]. Additionally, there is evidence showing that the two major pathways are linked and molecules from one can influence the other $[20,36]$.

\section{The Extrinsic or Death Receptor Pathway}

It involves binding of signal molecules (ligands) released by other cells to transmembrane death receptors, members of the tumor necrosis factor receptor gene (TNFR) superfamily [37,38] on the target cell to induce apoptosis. These receptors present similar cysteine-rich extracellular domains and a cytoplasmic one (80 amino-acids) called the "death domain" (DD) which plays a crucial role in transmitting the death signal from the cell surface to intracellular signalling. The best characterized ligands and corresponding receptors include FasL/FasR, TNF- $\alpha / T N F R 1$, Apo3L/DR3, Apo2L/DR4 and Apo2L/DR5 [29]. Apo2 ligand (also referred in the literature as TRAIL or TNF-related apoptosis inducing ligand) has sparked growing interest in oncology due to its reported ability to selectively trigger cancer cell death [39-41]. The best characterized sequence of events to date are those of FasL/FasR and TNF$\alpha /$ TNFR1 where clustering of receptors and binding with the homologous trimeric ligand occurs. Upon binding, cytoplasmic adapter proteins, exhibiting corresponding death domains, are recruited (FADD and TRADD, respectively) [26,33]. These will then associate with procaspase-8 via dimerization of the death effector domain, forming a death-inducing signalling complex (DISC) $[42,43]$. Caspase- 8 becomes activated and, in turn, directly activates caspase-3 (effector protein) to initiate degradation of the cell. Active caspase- 8 can also cleave Bid (pro-apoptotic) to tBid, which acts as a signal on the membrane of mitochondria to facilitate the release of cytochrome $c$ in the intrinsic pathway [34], representing a "cross-talk" of the two main pathways, amplifying the apoptotic signalling from death receptors [31].

\section{The Intrinsic or Mitochondrial Pathway}

The intrinsic pathway is triggered by several non-receptor mediated stimuli that produce intracellular signals that act directly on intracellular targets, initiated on the mitochondria, the Bcl-2 family members are being closely implicated in a regulatory role. Some stimuli involved include cellular stress, specifically mitochondrial stress caused by factors such as DNA damage or UV radiation [34]. Stimuli produce intracellular signals which can work 


\section{Extrinsic pathway}

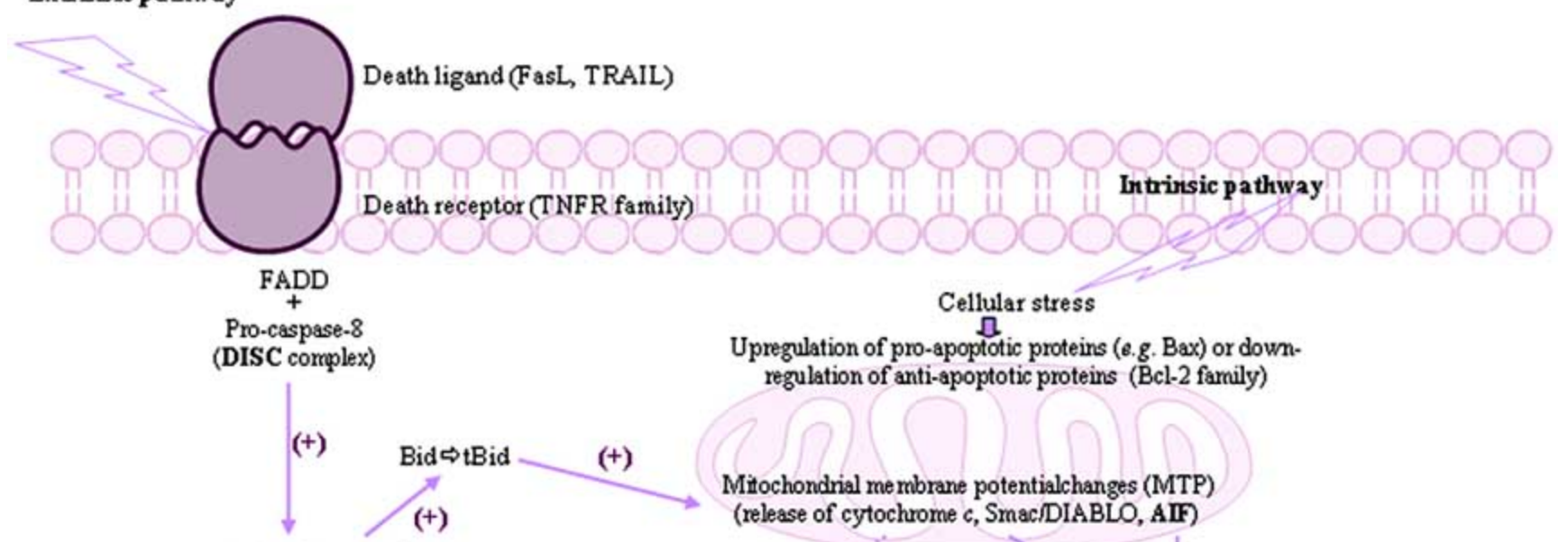

Active Caspase-8

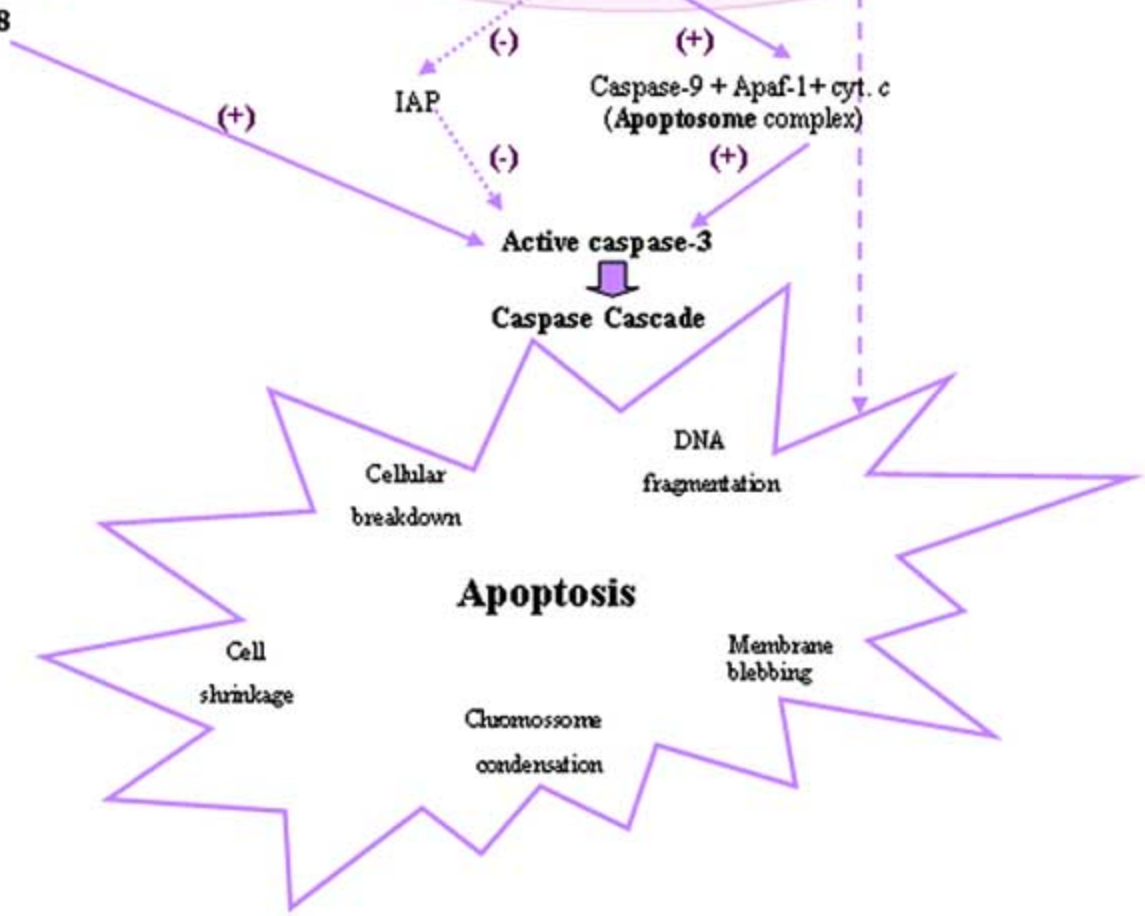

Fig. (1). Schematic drawing of the two major apoptotic pathways: the Extrinsic (or death receptor) and Intrinsic (or mitochondrial) pathways to caspase activation. The extrinsic pathway is triggered by activation of cell surface death receptors of the tumor necrosis factor receptor (TNFR) superfamily by ligands such as FasL or TNF-related apoptosis-inducing ligand (TRAIL), results in the recruitment to a trimerized receptor-ligand complex (DISC) through an adaptor protein with a death domain (e.g. FADD) and activation of initiator caspase-8. In the intrinsic pathway, cellular stress such as oncogene activation or DNA damage causes activation of the tumor suppressor p53 which leads to upregulation of several pro-apoptotic proteins (e.g. Bax, Bak) or inhibit (e.g. NOXA and PUMA) anti-apoptotic members of the Bcl-2 family, causing changes in the mitochondrial membrane potencial, and the release of pro-apoptotic molecules such as cytochrome $c$, Smac/DIABLO and apoptosis-inducing factor (AIF), from the inter-mitochondrial membrane space. The release of the cytochrome $c$ is regulated, at least in part, by the balance between pro-apoptotic (Bax, Bax and tBid) and anti-apoptotic (Bcl-2, Bcl-XL) members on the mitochondrial membrane. Once released, cytochrome $c$ binds to apoptotic-protease-activating factor 1 (Apaf-1), which results in the formation of the Apaf-1-caspase-9 apoptosome complex and activation of initiator caspase-9 (or induces apoptosis through a caspase-independent mechanism (e.g. AIF). The activated initiator caspases- 8 and -9 then activate effector caspase-3, -6 and -7 , which are responsible for the cleavage of crucial cellular substrates, resulting in the classical biochemical and morphological associated with the apoptotic phenotype.

in a positive or negative way. Negative signals are, for instance, the absence of certain growth factors, hormones and cytokines which normally suppresses apoptosis. Positive stimuli can be radiation, toxins, hypoxia, hyperthermia, free radicals (ROS/RNS) or others. These stimuli will cause changes in the inner mitochondrial membrane resulting in the opening of a mitochondrial permeability transition pore (MPT), loss of mitochondrial potential and release of normally sequestered pro-apoptotic molecules. Upon the stress signal, the pro-apoptotic proteins in the cytoplasm, Bax and Bid, bind to the outer membrane of the mitochondria to signal the release of the internal content. However, the signal of Bax and Bid is not enough to trigger a full release. Bak, another pro-apoptotic protein that resides within the mitochondria, is also needed to fully promote the release of cytochrome $c$ and the intramembrane content from the mitochondria. Following the release, cytochrome $c$ forms a complex in the cytoplasm with ATP and apoptotic protease-activa- 
ting factor-1 (Apaf-1). This complex will activate caspase-9 which will then form an apoptosome together with the complex of cytochrome $c$, ATP and Apaf-1 which, in turn, activates caspase-3, the effector protein that initiates degradation. Besides the release of cytochrome $c$ from the intramembrane space, the intramembrane content also contains Smac/DIABLO proteins [44] and the serine protease HtrA2/Omi, reported to promote apoptosis by inhibiting IAP (inhibitor of apoptosis proteins) activity [45]. Another group of pro-apoptotic proteins released from mitochondria during apoptosis (as a late event) includes AIF (apoptosis-inducing factor) [46], which translocates to the nucleus and causes DNA fragmentation and chromatin condensation [47], endonuclease G [48] and caspase activated DNase (CAD) [48,49].

The Bcl-2 family of proteins is responsible for the control and regulation of these apoptotic mitochondrial events [50,51], whith the tumor suppressor protein p53 playing a critical role in the regulation of their expression [34]. The members of the Bcl-2 family are categorized into two main groups. The first group consists of the anti-apoptotic members that share high structural and functional homology with $\mathrm{Bcl}-2$, while the second includes proteins that share less homology to $\mathrm{Bcl}-2$ and display pro-apoptotic activity. The latter group is further divided into two subgroups, the $\mathrm{Bcl}-2$-associated $\mathrm{X}$ protein (Bax)-like death factors and the BH3only proteins [51]. Some of the anti-apoptotic proteins include Bcl2, Bcl-x, Bcl-XL, Bcl-XS, Bcl-w, BAG and some pro-apoptotic include Bcl-10, Bax, Bak, Bid, Bad, Bim, Bik and Blk, with at least 25 genes identified to date [31]. The anti-apoptotic gene products are initially integral membrane proteins, localized mainly in the mitochondrial outer membrane and have been also detected in the membranes of the ER and nucleus [52,53]. Their main role is to stabilise the mitochondrial membrane, preventing cytochrome $c$ release and its subsequent binding to Apaf-1 $[54,55]$. By contrast, the pro-apoptotic Bcl-2 family members localise to cytosol or cytoskeleton, in a healthy cell. However, following a death signal, they usually interact with the anti-apoptotic proteins, resulting in their inhibition and the initiation of the apoptotic machinery. It is accepted that the main mechanism of action of these proteins is the regulation of cytochrome $c$ release via alteration of the permeability of the mitochondria membrane. Overall, the relative ratio of prosurvival (Bcl-2-like) and pro-apoptotic (Bax-like and BH3-only) proteins seems to determine the cell sensitivity or resistance to the apoptotic stimuli [31,51].

The extrinsic and intrinsic pathways will both end at the point of the execution phase: execution caspases activate cytoplasmic endonuclease which degrades nuclear material and proteases that degrade nuclear and cytoskeletal proteins. Such executioners include caspase-3 (considered the most important executioner caspase $[20,31,33])$ that can be activated by any of the initiator caspases (caspase-8, -9 or -10 ). Gelsolin, an actin binding protein, is a key regulator of actin filament assembly, linking actin organization and signal transduction, and inhibits apoptosis. Caspase- 3 will cleave gelsolin and the resultant fragments will cleave actin in a $\mathrm{Ca}^{2+}$-independent manner causing disruption of cytoskeleton, intra-cellular transport, cell division and signal transduction [56].

In addition to $\mathrm{p} 53$, the extrinsic and intrinsic apoptotic pathways are also regulated by $\mathrm{NF}-\kappa \mathrm{B}$, ubiquitin proteosome system and PI3K pathways [57].

p53 is a transcription signal which regulates downstream effectors important in cell signalling arrest, DNA repair and apoptosis; after DNA damage, p53 holds the cell at the checkpoint until damage is repaired. If damage is irreversible then apoptosis is triggered [58].

$\mathrm{NF}-\mathrm{\kappa B}$ is a nuclear transcriptional factor that regulates expression of a large number of genes involved in apoptosis regulation, viral replication, tumorigenesis, inflammation and many autoimmune diseases [59]. It is activated by several stimuli such as cytokines limphokines, radiation, pharmacologic agents and oxidative stress. It is present in its inactive form bound to IKB inhibitory proteins but once activated can present both antiapoptotic and pro-apoptotic functions: physiologically it induces resistance to apoptosis through activation of IAP and X-linked IAP. However, some stimuli leading to NF- $\kappa \mathrm{B}$ activation may induce apoptosis probably due to the activation of pro-apoptotic proteins such as c-myc, p53 and caspase-1 [60].

The ubiquitin/proteosome system is constituted of a large proteinase complex, responsible for the turnover of most intracellular proteins and, consequently, regulates cell growth and apoptosis: protein regulation proceeds by recognition of proteins by multiple ubiquitin molecules and posterior digestion by $26 \mathrm{~S}$ proteosome; many cell cycle regulators and transcription factors, namely p53, cyclins and cyclin-dependent kinase inhibitors and NF$\kappa \mathrm{B}$ and many of the $\mathrm{Bcl}-2$ proteins, are regulated by this system $[61,62]$.

$\mathrm{PI} 3 \mathrm{~K}$ is a kinase playing crucial roles in signalling pathways important to cell survival, proliferation, motility and tissue neovascularization and is up-regulated in many cancers [63]. In simple terms, PI3K activates kinase Akt, which in turn is involved in the activation of proteins that promote cell survival, namely NF-кB. Phosphorylation of Bad or caspase by Akt also blocks apoptosis [57].

One of the hallmarks of apoptosis is the cleavage of chromosomal DNA into nucleosomal units. Caspases play an important role in this process by activating DNases, inhibiting DNA repair enzymes (poly (ADP-ribose) polymerase (PARP) by caspase-3) and breaking down structural proteins (e.g. lamins by caspase-6) in the nucleus. The fragmentation of DNA into nucleosomal units is caused by CAD, existing as an inactive complex with ICAD (inhibitor of CAD). During apoptosis, ICAD is cleaved by caspases (e.g. caspase 3) releasing $\mathrm{CAD}$ which then leads to the rapid fragmentation of the nuclear DNA.

\section{CANCER, APOPTOSIS AND CHEMOPREVENTION}

Apoptosis is a genetically regulated form of cell death that occurs in response either to physiological, pathogenic or cytotoxic stimuli. Apoptotic processes are of widespread biological significance, being involved in e.g. development, differentiation, cell proliferation/homeostasis, regulation and function of the immune system and in the removal of harmful cells (cells damaged by aging or by exposure to DNA-damaging agents or viruses) [20, 26,31]. As such, dysfunction or deregulation of apoptosis has been implicated in the pathogenesis of a variety of pathological conditions, namely autoimmune diseases, spreading of viral infections, neurodegenerative diseases, ischemic damage and cancer [20,26,31]. The role of apoptosis in cancer has probably received the greatest research effort [44,57,64-69].

Cancer is an example of a pathologic condition where the normal mechanisms of cell cycle regulation are dysfunctional either by excessive cell proliferation, insufficient apoptosis or both $[26,65,67]$. More than 35 years ago, when apoptosis was first described, authors have already suggested that this type of cell death was important not only for the elimination of potencially malignant (DNA-damaged), and for therapeutically induced tumor regression but also for tumor progression [67]. Suppression/ inhibition of apoptosis during carcinogenesis is accepted to play a role in the development and progression of cancers [67-69]. At present, it is accepted that cell populations are tightly regulated by their rates of proliferation, differentiation and death. When the homeostatic balance is disturbed in such a way that clonal outgrowth of mutated cell populations may occur, the development of a tumor will proceed [67-69].

In simple terms, one can define carcinogenesis as a multistage process where a normal cell becomes transformed into one with a 
malignant phenotype. Cells become initiated by the acquisition of an activating mutation in an oncogene or an inactivation mutation in a tumor suppressor gene (Initiation). Several additional factors confer these cells a growth advantage (Promotion), which survive accumulating abnormal characteristics and ultimately progressing to a metastatic tumor (Progression) [70]. It has been suggested that, at least, six essential alterations in cell physiology are needed in order to malignant growth occur: self-sufficiency in growth signals, insensitivity to growth inhibitory signals, evasion of cell death, limitless replicative potential, sustained angiogenesis and metastasis formation [70]. Carcinogenesis is, therefore, a complex process driven by tight interaction between oncogene activation, tumor suppressor inactivation and cell death machinery. Early in transformation, activated oncogenes that drive the cell to uncontrolled proliferation simultaneously triggers apoptosis, probably as a safety mechanism that removes cells carrying mutations in oncogenes [71]. Later in tumorigenesis, the supply of nutrients and oxygen becomes limited, with the tumor cells undergoing hypoxia-induced apoptosis [72]. In order to survive, tumor cells acquire apoptoticinhibiting mutations (reduced apoptosis) [72]. Failures in normal apoptosis pathways contribute to carcinogenesis by creating a permissive environment for genetic instability and accumulation of mutations, promoting resistance to immune-based destruction, disobeyence of cell-cycle checkpoints (that would normally induce apoptosis), facilitating growth factor/hormone-independent cell survival, supporting anchorage-independent survival during metastasis, reducing dependence on oxygen and nutrients, and conferring resistance to cytotoxic anticancer drugs and radiation [67]. In summary, inhibition of apoptosis can allow tumor development: in animal models, most chemical initiators are not able to cause tumors unless a promoter is subsequently applyed. Many tumor promoters inhibit apoptosis in vitro [73]. This represents the main reason why activation of apoptosis is being considered one of the most promising therapeutic approaches in cancer therapy [57, 67,74]. Tumor cells can acquire resistance to apoptosis, for instance, by overexpressing anti-apoptotic proteins such as Bcl-2 or down-regulate/mutate pro-apoptotic proteins such as Bax, the expression of both being regulated by the p53 tumor suppressor gene $[75,76]$. The tumor suppressor gene $p 53$ is a transcription factor essential for the prevention of cancer formation and it can be damaged by radiation, several chemicals and viruses such as the HPV. The $p 53$ pathway is ubiquitously lost in human cancer either by $p 53$ gene mutation ( $60 \%$ of cancers) or by loss of cell signalling upstream and downstream of p53 in the remaining cancers expressing WTp53 gene [77]. Therefore, despite enthusiasm towards apoptosis based-drugs, possible difficulties are also being anticipated such as selection of apoptosis-resistant tumor cells and systemic toxicity [74].

Several epidemiological studies, later evaluated by metaanalysis, had identified associations between certain dietary factors and cancer either increasing or decreasing cancer risk [78-80]. It is currently accepted that diet can affect the overall process of carcinogenesis by different mechanisms: its constituents may contain cancer causing substances but can also present many cancer preventive agents. These dietary agents can retard or prevent the process of carcinogenesis by multiple mechanisms, namely i) enhanced detoxification of the carcinogenic intermediates through induction of Phase 2 drug metabolizing enzymes ii) reduced carcinogen activation due to suppression of cytochrome P450dependent monooxidases, iii) perturbations in cell cycle progression, iv) selective promotion of apoptosis in cancerous or precancerous cells and v) inhibition of angiogenesis and metastasis formation [81]. Since apoptosis provides a physiologic mechanism for eliminating abnormal cells, dietary factors affecting apoptosis can present important effects on carcinogenesis. Conceivably, activation of apoptosis in pre-cancerous cells offers a prevention mechanism of cancer by dietary factors. In fact, most initiated cells are destroyed by apoptosis before they became malignant and part of a tumor [69]. Research and increasing understanding in the field of cancer has led to the conviction that most human malignancies should be fought on multiple fronts: in addition to cancer therapy cancer prevention has become an important means of controlling cancer $[1,27]$. Common prevention strategies include avoiding exposure to known cancer-causing agents, enhancement of hostdefense mechanisms against cancer, life style modifications and chemoprevention [27].

The term chemoprevention refers to the use of agents to slow the progression of, reverse or inhibit carcinogenesis and was first introduced by Sporn and co-workers in the mid-1970's. In respect to cancer chemoprevention, animal studies, clinical trials and in vitro studies have studied the anticancer activity of numerous putative chemopreventive agents. These studies strongly suggest that apoptosis induction is associated with anti-cancer activity of many of these compounds supporting the notion that apoptosis is a novel target for cancer chemoprevention [27,82]. Moreover, the pro-apoptotic properties of a variety of chemopreventive agents, like those of many conventional and experimental cancer chemotherapeutic agents, appear to be related to alterations of mitochondria in tumor cells $[82,83]$. In fact, several classes of chemopreventive agents contain members that trigger mitochondrial disruption and/or mitochondrial-mediated apoptosis (intrinsic pathway) in tumor cells in vitro although other may induce apoptosis via death receptor pathway [28].

Chemotherapy aims to kill cancer cells, in the hope of preventing further cancer progression. Chemoprevention, on the other hand, involves administering non-toxic agents to individuals who may be at increased risk for cancer. Moreover, surgical and traditional therapeutic approaches (chemotherapy and radiation) are, at present, unable to control most cancer types. This urges the need of developing new chemopreventive strategies [82,84-87]. Chemopreventive compounds can be classified into two major groups: blocking agents, which prevent carcinogens from reaching or reacting with critical target sites and suppressing agents which stop the evolution of the pre-neoplastic process. Given that the Initiation and Progression phases are relatively transient and irreversible events, it seems logical that chemopreventive agents should intervene at the prodromal Promotion phase. Three decades of research suggested chemoprevention as a promising strategy to reduce the incidence of cancer, both in well-defined high-risk groups and in the general population [82, 84-88]

\section{CHEMOPREVENTIVE DIETARY COMPONENTS}

An effective chemopreventive agent should preferably intervene early in the process of carcinogenesis to eliminate pre-malignant cells before they become malignant. Many chemopreventive agents are able to block or delay the promotion and/or progression of malignant cells by modulating cell proliferation and/or differentiation $[27,82]$ and, therefore, these should be chronically administered to individuals with higher risk of cancer development. Using this approach, even minor adverse effects would be unacceptable: obstacles to the use of chemoprevention for many cancers can be issues like long-term toxicity and the development of chemoresistance [27]. These issues can limit the feasibility and success of conventional forms of chemoprevention for many cancers. Alternative approaches involves the use of agents that eliminate cells through an expedite way. Using agents capable of inducing apoptosis in tumor cells (preferably using targeted delivery) would also prevent the need for chronic exposure, limiting the risk of long term toxicity and/or the development of chemoresistance [27].

An ideal chemopreventive agent should be selective for damaged or transformed cells, display a significant bioavailability in the target region and have more than one mechanism of action. Moreover, it should be highly effective, easy to administer, and inexpensive. Dietary compounds are particularly attractive because 
of human long-standing exposure to them, their relative lack of toxicity, and encouraging indications from epidemiological studies [87], an important drawback being, however, their possible low bioavailability after ingestion $[88,89]$. In addition to conventional therapeutic agents, numerous dietary components and micronutrients are emerging, with considerable potential for hindering in vivo deleterious oxidative processes and inducing apoptosis of cancer cells.

Food, a readily available item, contains several promising chemopreventive compounds [20,78,81]. Plant polyphenols, ubiquitous in a diet rich in vegetables and fruits, are serious candidate for being responsible for the cancer protective effects ascribed to this type of diet $[22,23,89]$. In fact, numerous phenolic compounds were shown to display antiproliferative and cytotoxic effects towards several tumor cells, presenting toxicity-specific for cancer cells comparing to normal cells [90-93]. Dietary polyphenols are mainly consumed through fruits and beverages (juice, wine, tea, coffee, chocolate and beer), apart from vegetables, cereals and olive derivatives, food components mainly associated to the mediterranean diet [95-99]. Their average daily intake has been reported to be around $1 \mathrm{~g}[89,100]$, which is much higher than intake of all other classes of dietary antioxidants: for instance it is approximately 10 times higher than vitamin $\mathrm{C}$ intake and 100 times the intakes of vitamin $\mathrm{E}$ and carotenoids [100].

Additionally to their antioxidant properties, polyphenols display very interesting biological effects in animal models and in vitro systems. These compounds are able to trap and scavenge free radicals, decrease leukocyte immobilization, induce apoptosis, inhibit cell proliferation and angiogenesis and exhibit phytoestrogenic activity [101-103]. The possible biological mechanisms and signal transduction pathways related to the chemopreventive properties of dietary polyphenols were also addressed by our group in a recent review [25]. Laboratory works published between 1995 and 2005 were reviewed and revealed that these dietary compounds have the ability to interfere with signal transduction pathways related to the carcinogenesis process, acting as chemopreventive agents: suppression of NF- $\kappa \mathrm{B}$ transcription factor activation; suppression of AP-1 transcription factor activation, suppression of mitogen activated protein kinases (MAPK), suppression of protein kinases (PKs), suppression of growth-factor receptor (GFR)-mediated pathways, cell cycle arrest and induction of apoptosis, antioxidant and anti-inflammatory effects and suppression of angiogenesis [25].

As previously stated, the pro-apoptotic properties, most probably mitochondrial-induced apoptosis, of a variety of compounds can be directly related to their chemopreventive properties, $[27,82]$. Pro-apoptotic diet-derived compounds can conceivably protect from cancer by enhancing elimination of initiated, precancerous cells. Polyphenols present pro-apoptotic ability towards malignant or pre-malignant cells. A large variety of plant polyphenols exist in human diet, including phenolic acids and analogues, stilbenes, chalcones and tannins (Table 1), flavonoids and analogues, coumarins, anthocyanins and lignans (Table 2). Tables $\mathbf{1}$ and $\mathbf{2}$ show the chemical structures of the different polyphenols families, trivial names of representative compounds from each family, their dietary source and apoptosis induction marker studied.

Table 1. Diet-Derived Phenolic Compounds with Pro-Apoptotic Properties

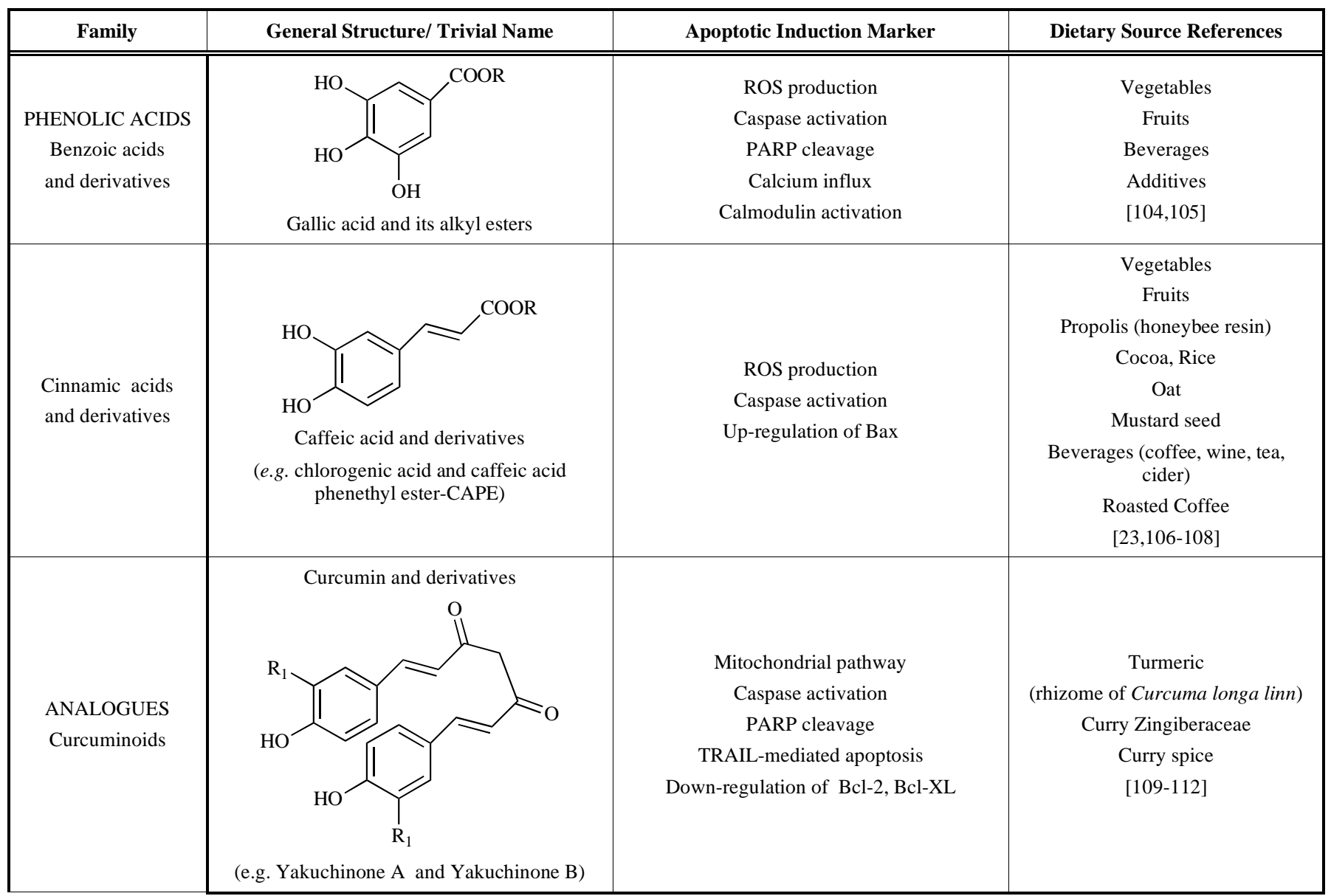


(Table1) Contd....

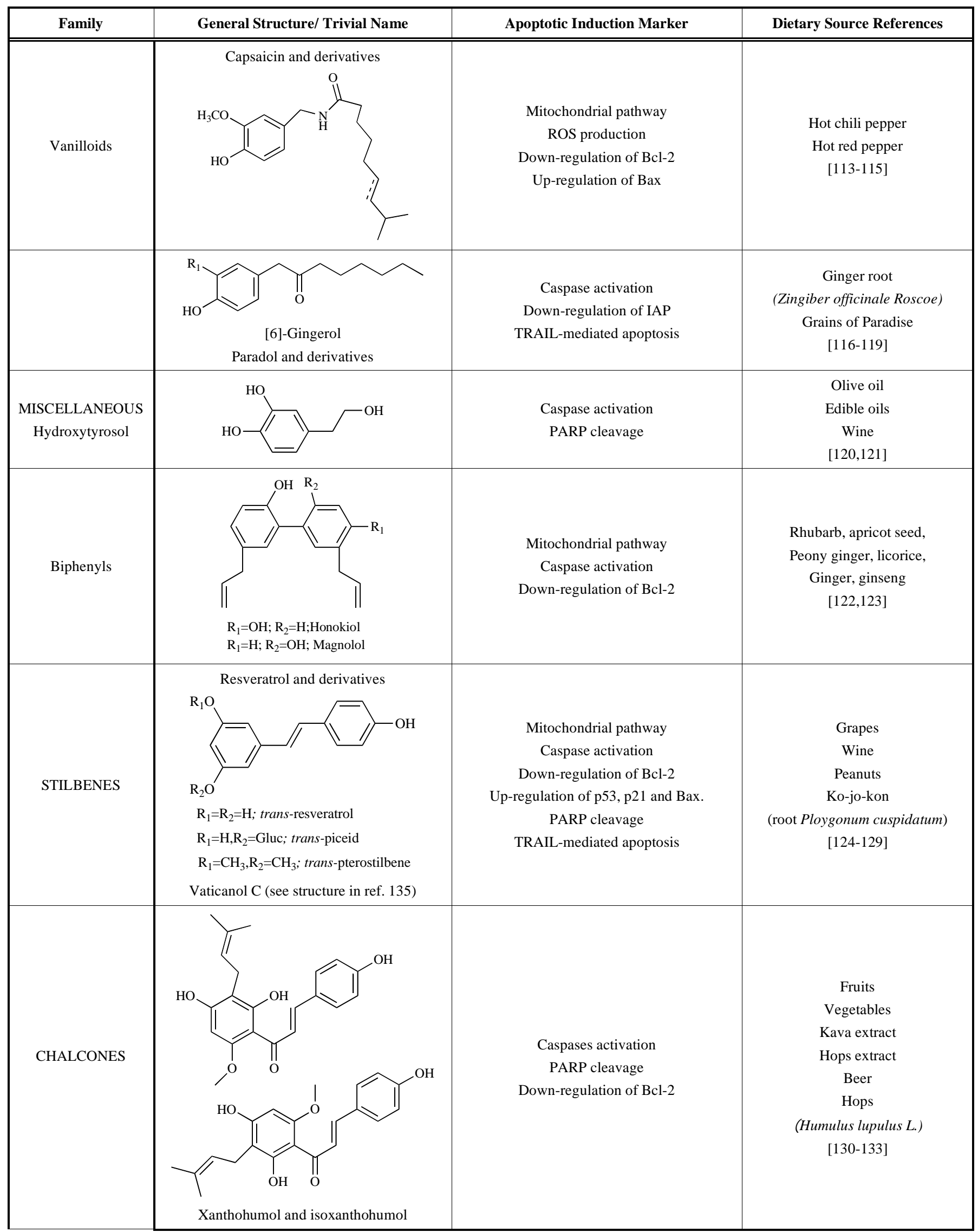


(Table 1) Contd....

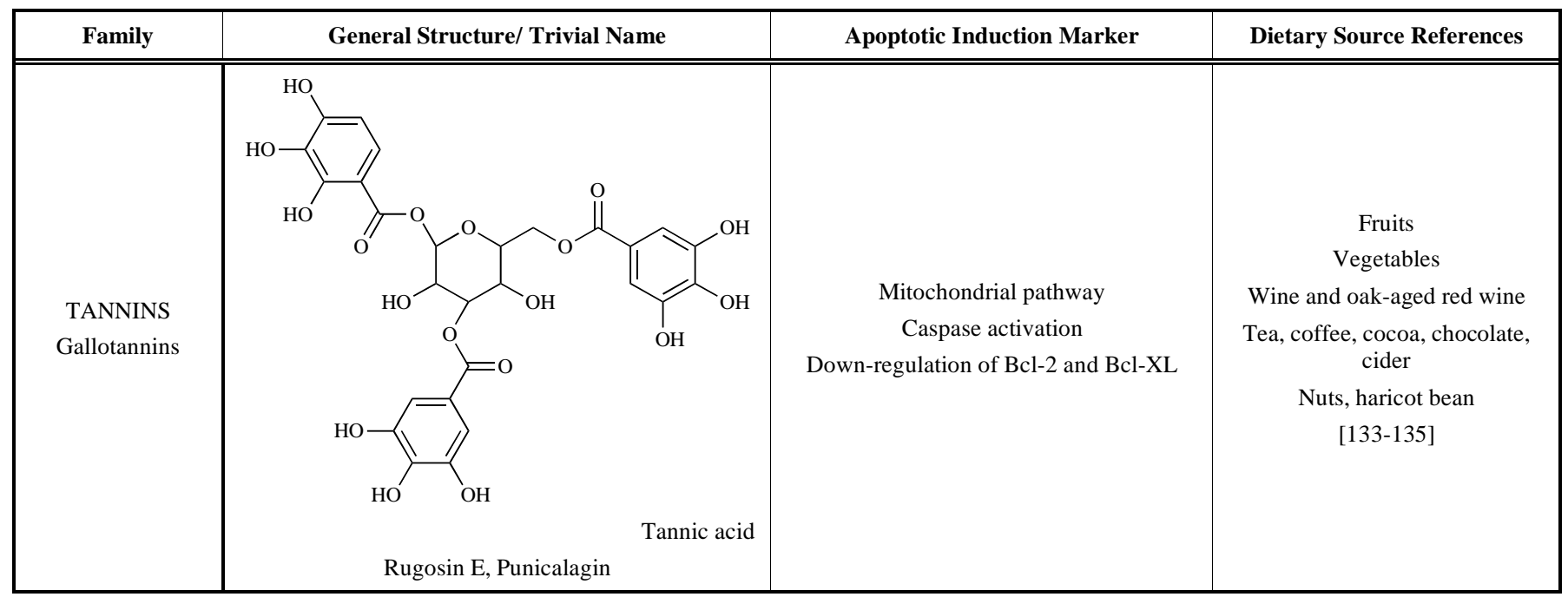

Table 2. Diet-Derived Phenolic Heterocyclic Compounds with Pro-Apoptotic Properties

\begin{tabular}{|c|c|c|c|}
\hline Family & Structure /Trivial Name & Apoptotic Induction Marker & $\begin{array}{c}\text { Dietary Source } \\
\text { References }\end{array}$ \\
\hline $\begin{array}{c}\text { FLAVONOIDS } \\
\text { Flavonols }\end{array}$ & 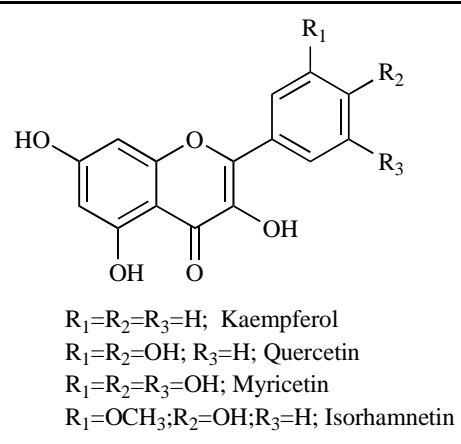 & $\begin{array}{c}\text { ROS production } \\
\text { Caspases activation } \\
\text { TRAIL-mediated apoptosis } \\
\text { Down-regulation of Bcl-2, c-myc } \\
\text { and H-ras } \\
\text { Up-regulation of Bax, c-fos and } \\
\text { p53 }\end{array}$ & $\begin{array}{c}\text { Fruits } \\
\text { (grapes, citrus } \\
\text { fruits, berries) } \\
\text { Vegetables } \\
\text { Olive oil } \\
\text { Red wine } \\
\text { Tea } \\
\text { Cocoa } \\
\text { [136-142] }\end{array}$ \\
\hline Isoflavones & $\begin{array}{l}\mathrm{R}_{3}=\mathrm{R}_{2}=\mathrm{OH} ; \mathrm{R}_{3}=\mathrm{H} ; \text { Daidzein } \\
\mathrm{R}_{1}=\mathrm{R}_{2}=\mathrm{R}_{3}=\mathrm{OH} ; \text { Genistein }\end{array}$ & $\begin{array}{c}\text { Caspase activation } \\
\text { Activation of calcium dependent } \\
\text { endonuclease } \\
\text { TRAIL-mediated apoptosis }\end{array}$ & $\begin{array}{c}\text { Soy, soybeans } \\
\text { Soymilk and other } \\
\text { soy products } \\
\text { Flour-processed } \\
\text { products } \\
\text { Legumes } \\
\text { Citrus fruits } \\
\text { Grape seed } \\
\text { [151-153] }\end{array}$ \\
\hline
\end{tabular}


(Table 2) Contd....

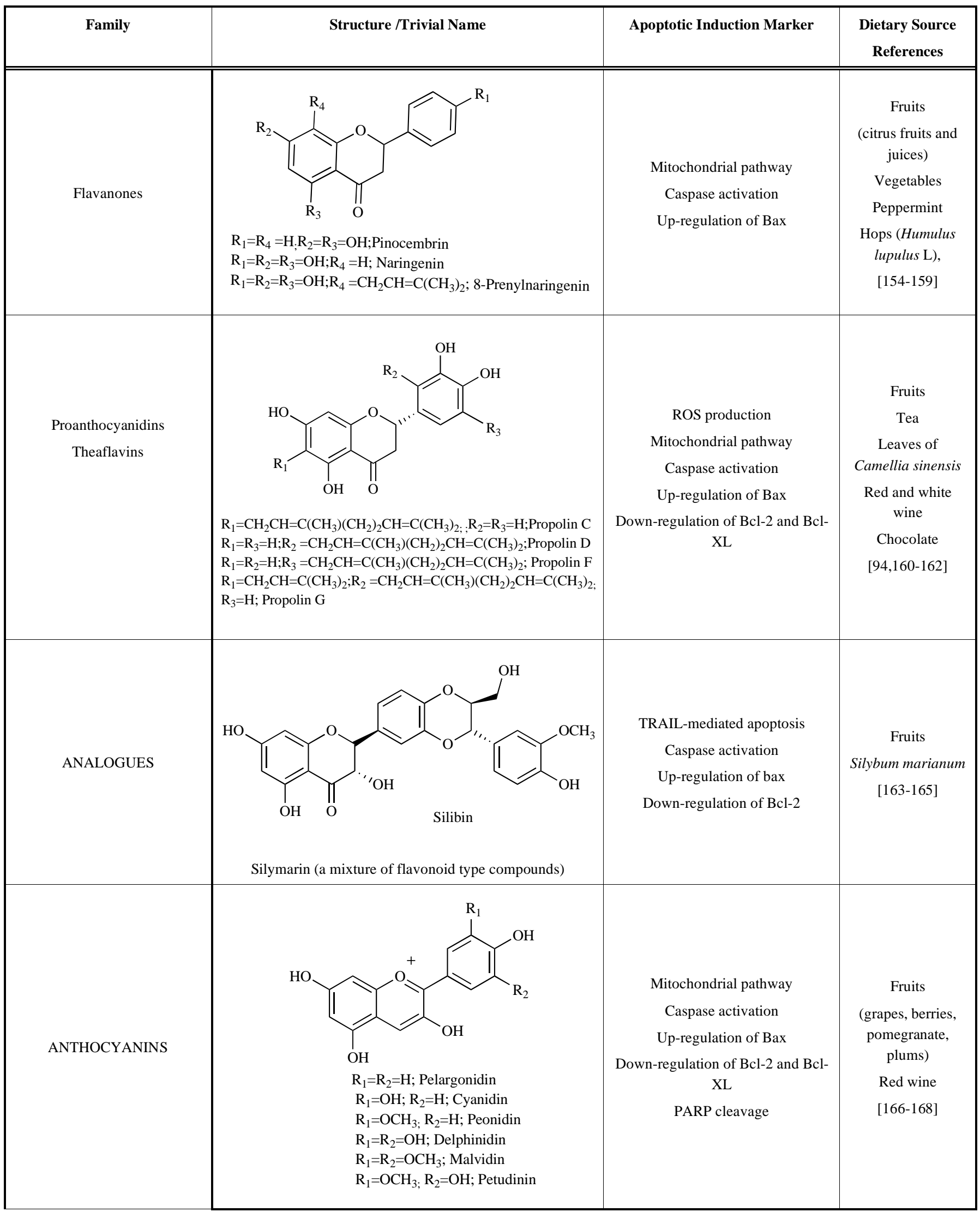


(Table 2) Contd....

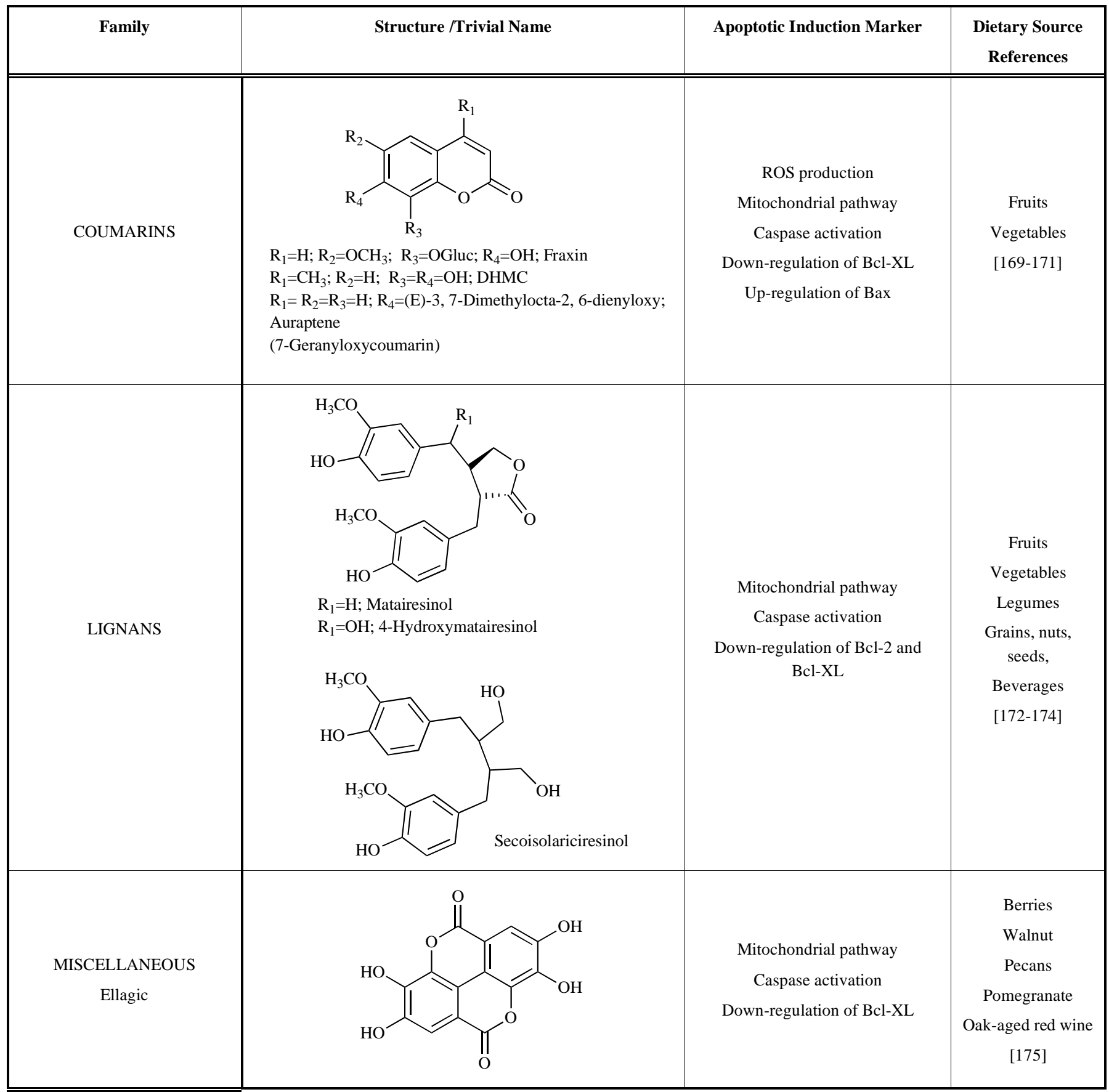

Overwelming evidence can be found in the literature on the proapoptotic properties of dietary polyphenols against numerous types of human cancer cell lines, from colon and prostate cancers, to breast adenocarcinoma and leukaemia [176,177]. Among many others apoptosis was reported to be induced by anthocyanidins [166] and epicathechin in hepatoma cell lines; by epigallocatechin3-gallate (EGCG) [178] and pterocarnin [179] in breast adenocarcinoma MCF-7 cells; by quercetin in oral squamous carcinoma [137], leukaemia [180,181], breast [182,183], lung [184], prostate [185,186] and colon cancer cell lines [187]; by gallotannin in human colon cancer cell lines [188]; by resveratrol in prostate cancer [189]; by genistein in breast [190,191], prostate [192,193], gastrointestinal [194], lung [195], and head and neck cancer cell lines [196,197]; by persimmon extract (Diospyros kaki) and related polyphenols in lymphoid leukaemia cells [198] or by olive oil polyphenol-rich extract in AGS stomach cancer cells [199].

Studies carried out indicate that phenolic concentrations leading to apoptosis are within the micromolar range: for example concentrations ranging from $29 \mu \mathrm{M}$ to $150 \mu \mathrm{M}$ have been reported for quercetin [200,201], and 30-200 $\mu \mathrm{M}$ for genistein [190,191]. In general, the effective concentrations required for induction of apoptosis are higher than those leading to growth inhibition. However, there are some reports on induction of apoptosis without inhibition of cell proliferation (e.g. EGCG effect on H661 lung cancer cells [202]). Further increases in polyphenol concentration may cause necrosis of all cells tested (i.e. loss of specificicity for malignant cells occurs). In addition, decreased cell viability can be 
Table 3. Examples of Phenolic Diet Extracts with Pro-Apoptotic Properties

\begin{tabular}{|c|c|c|}
\hline Extracts & Phenolic Content & References \\
\hline $\begin{array}{l}\text { Grape seed } \\
\text { Wine } \\
\text { Beer }\end{array}$ & $\begin{array}{l}\text { Phenolic acids, Stilbenes, Proanthocyanins, Anthocyanins, } \\
\text { Flavonoids, Chalcones, Tannins }\end{array}$ & [203-208] \\
\hline $\begin{array}{l}\text { Berries, Pomegranate } \\
\text { Prune, Avocado }\end{array}$ & $\begin{array}{l}\text { Anthocyanins, Flavonols, } \\
\text { Flavanols, Gallotannins, Proanthocyanidins, Phenolic Acids }\end{array}$ & [209-212] \\
\hline $\begin{array}{l}\text { Tea (black and green), Decaffeinated tea } \\
\text { Chamomile }\end{array}$ & $\begin{array}{c}\text { Theaflavins } \\
\text { Epicatechin, Epicatechin gallate } \\
\text { Epigallocatechin, Tannins }\end{array}$ & [213-215] \\
\hline Roasted Coffee & $\begin{array}{l}\text { Cinnamic acids } \\
\text { Ellagic acid }\end{array}$ & [216] \\
\hline Propolis & Phenolic acids, CAPE, Flavonoids & [217] \\
\hline Rice & Phenolic acids & [218] \\
\hline Ginger & Vanilloids, Biphenyls & [219] \\
\hline Soy, soybean and hole-grain & Flavonoids (Isoflavones) & [220] \\
\hline Olives, Edible oils & Tirosol derivatives & {$[221,222]$} \\
\hline Sesame seed & Lignans & [223] \\
\hline Potato & Anthocyanins, Phenolic acids & [224] \\
\hline
\end{tabular}

due both to polyphenol-induced apoptosis and necrosis (at high concentrations), sometimes after 48 hours of exposure to the phenolic agent [192].

In this section the pro-apoptotic properties of diet components, with particular emphasis on polyphenols, were reviewed. Table $\mathbf{3}$ describes the polyphenol composition of several dietary extracts with proved pro-apoptotic activity.

Recent evidence suggests the occurrence of a synergistic effect of different dietary phenolic compounds, and a possible role as enhancers of effects of established anticancer agents [225,226]: EGCG and curcumin towards premalignant and malignant human oral epithelial cells [227]; resveratrol and quercetin in human pancreatic cancer cells [200]; quercetin and ellagic acid in human leukaemia MOLT-4 cells [228]; EGCG and sulindac or tamoxifen against human PC-9 lung cancer cells [229]; quercetin and cisplatin towards human laryngeal Hep2 cells [230] and HeLa adenocarcinoma cells [231]. This recognized synergy among dietary phenols and conventional synthetic drugs provides an interesting approach to combination therapy or to pre-treat neoplastic cells with polyphenolic agents. This strategy has been able, in some cases, to even overcome chemoresistance [232]. At present, several phytochemicals (vincristine, vinolrelbine, teniposide, paclitaxel, docetaxel and some water-soluble analogs of camptothecin [233]) are used in mainstream cancer therapy strategies. However, commercial plant-derived anticancer formulations represent only one-fourth of the available treatment options.

Research has shown that anti-carcinogenic and cytotoxic activities of polyphenols are largely determined by structural parameters, as much as their antioxidant potency [93, 234-237]. Despite their close resemblance, their bioactivity varies considerably upon minor structural modifications, since these often induce significant conformational changes [25,238-244]. This implies an important drawback in the understanding of the effects of polyphenols in human health if one considers the huge number of different compounds (> 8000; [88]).

Their bioavailability, is also strongly affected by structural factors, namely the extent, localisation and/or nature of the ring substitution, or the length and saturation degree of ester/amide alkyl chains but may also be influenced by intracellular metabolic processes, conjugation with other biomolecules (e.g. polyamines and glycosides), or in vivo absorption and transport mechanisms. Nevertheless, studies which indicate those factors which would lead to a better bioavailability are still scarce at present. Most in vitro studies use native polyphenols which may well be totally different from those found in the body. Polyphenols can be metabolized by bacteria before absorption and are also extensively conjugated in the body [88]. Very little is known, at present, related to the activity of these conjugated metabolites but, for instance, glucuronides of isoflavones have much weaker anti-estrogenic activity and provided no protection against oxidative stress in cells [278]. These facts explain the need to re-evaluate many of the in vitro studies published to date. Further studies are needed to tailor rational design of polyphenolic derivatives with improved chemopreventive properties [25].

In addition to the accepted beneficial effects of polyphenols against oxidative stress in normal cells (anti-oxidant, antiinflammatory, anti-cancer) $[25,245,246]$, these compounds can also cause pro-oxidant deleterious effects, depending on the specific system and conditions investigated. One possible, although insufficiently investigated, mechanism explaining phenol toxicity can be related to their pro-oxidant properties, which can accelerate oxidative processes in vitro, damaging DNA, proteins or carbohydrates in the cell [93,247-251]. The same phenolic compound can behave both as antioxidant and pro-oxidant, stimulating or inhibiting the oxidative damage processes to biomolecules, depending 
Table 4. Examples of Diet-Derived Compounds with Pro-Apoptotic Properties

\begin{tabular}{|c|c|c|c|}
\hline Family & Compound (s) Trivial Names & Apoptotic Induction Marker & $\begin{array}{c}\text { Dietary Source } \\
\text { References }\end{array}$ \\
\hline $\begin{array}{c}\text { RETINOIDS } \\
\text { CAROTENOIDS }\end{array}$ & $\begin{array}{c}\text { All-trans-retinoid acid } \\
\text { Retinyl esters, Retinol } \\
\alpha \text {-Carotene, } \beta \text {-Carotene } \\
\gamma \text {-Carotene } \\
\text { Lutein, lycopene } \\
\beta \text {-Cryptoxanthin, astaxanthin, zeaxanthin }\end{array}$ & $\begin{array}{c}\text { ROS production } \\
\text { Mitochondrial pathway } \\
\text { Caspase activation } \\
\text { Down-regulation of Bcl-2 } \\
\text { Up-regulation of Bax }\end{array}$ & $\begin{array}{l}\text { Yellow/orange fruits (Tomato, } \\
\text { carrots) } \\
\text { Vegetables } \\
\text { Marine food } \\
\text { Salmon } \\
{[262-265]}\end{array}$ \\
\hline $\begin{array}{l}\text { SULFUR-CONTAINING } \\
\text { COMPOUNDS }\end{array}$ & $\begin{array}{c}\text { Isothiocyanates } \\
\text { (allyl isothiocyanate, benzyl isothiocyanate, } \\
\text { phenethyl isothiocyanate, sulforaphane) } \\
\text { Organo sulfur compounds } \\
\text { (diallyl sulfide, diallyl disulfide, diallyl } \\
\text { trisulfide S-allyl cysteine (allium), allicin } \\
\text { (garlic)) }\end{array}$ & $\begin{array}{c}\text { ROS production } \\
\text { Caspase activation } \\
\text { Down-regulation of Bcl-2 } \\
\text { Up-regulation of Bax }\end{array}$ & $\begin{array}{l}\text { Cruciferous vegetables } \\
\text { Garlic, brussels sprouts, broccoli, } \\
\text { watercress, garden cress, turnips, } \\
\text { Onions, callions } \\
\text { Essential oils } \\
\text { [266-268] }\end{array}$ \\
\hline INDOLES & $\begin{array}{l}\text { Indole phytoalexins (e.g. Brassinin) } \\
\text { Indole-3-carbinol }\end{array}$ & $\begin{array}{c}\text { Mitochondrial pathway } \\
\text { Caspase activation } \\
\text { Down-regulation of Bcl-2 } \\
\text { Up-regulation of Bax }\end{array}$ & $\begin{array}{l}\text { Cruciferous vegetables } \\
\qquad[269-271]\end{array}$ \\
\hline VITAMINS & $\begin{array}{c}\text { Tocopherols, Tocotrienols } \\
\text { Riboflavin } \\
\text { Vitamin D } \\
\text { Vitamin K }\end{array}$ & $\begin{array}{c}\text { ROS production } \\
\text { Mitochondrial pathway } \\
\text { Caspase activation } \\
\text { PARP cleavage }\end{array}$ & $\begin{array}{c}\text { Fruits } \\
\text { Vegetables } \\
{[272-274]}\end{array}$ \\
\hline $\begin{array}{c}\text { INORGANIC } \\
\text { MICRONUTRIENTS }\end{array}$ & Selenium derivatives & $\begin{array}{c}\text { ROS production } \\
\text { Mitochondrial pathway } \\
\text { Caspase activation }\end{array}$ & $\begin{array}{c}\text { Meat, wheat, dairy, fish } \\
\text { [275-277] }\end{array}$ \\
\hline DIETARY FIBRE & $\begin{array}{c}\text { Lignin or suberin } \\
\text { Phenolic acids } \\
\text { Inositol hexaphosphate }\end{array}$ & Caspase activation & $\begin{array}{l}\text { Unrefined plant foods } \\
\qquad[278]\end{array}$ \\
\hline TERPENOIDS & $\begin{array}{l}\text { Citral } \\
\text { Limonene, Perillyl alcohol } \\
\text { Betulinic acid } \\
\text { Ursolic acid } \\
\text { Geranylgeraniol } \\
\text { Farnesol }\end{array}$ & $\begin{array}{c}\text { Mitochondrial pathway } \\
\text { Caspase activation } \\
\text { Up-regulation of Bax } \\
\text { Down-regulation of Bcl-2 and Bcl-XL }\end{array}$ & $\begin{array}{c}\text { Plants } \\
\text { Citrus fruits and oils } \\
\text { Essential oils } \\
\text { Apples, pears, prunes } \\
\text { Chamomile } \\
\text { Hops } \\
{[279-285]}\end{array}$ \\
\hline METHYLXANTHINES & Caffeine, theophylline, theobromine & Controversial & $\begin{array}{c}\text { Tea, coffee, } \\
\text { cola, cacao (cocoa and chocolate) } \\
{[286,287]}\end{array}$ \\
\hline ALKALOIDS & $\begin{array}{c}\text { Solamargine } \\
\text { Solasodine glycosides }\end{array}$ & $\begin{array}{c}\text { Mitochondrial pathway } \\
\text { Caspase activation } \\
\text { Up-regulation of Bax } \\
\text { Down-regulation of Bcl-2 and Bcl-XL }\end{array}$ & $\begin{array}{c}\text { Potatoes } \\
\text { Eggplants } \\
\text { Tomatoes, } \\
\text { [288] }\end{array}$ \\
\hline
\end{tabular}


(Table 4) Contd....

\begin{tabular}{|c|c|c|c|}
\hline Family & Compound (s) Trivial Names & Apoptotic Induction Marker & $\begin{array}{c}\text { Dietary Source } \\
\text { References }\end{array}$ \\
\hline POLYSACCHARIDES & $\begin{array}{c}\text { Carboxymethylated } \beta \text {-glucan } \\
\text { Chitin, chitosan }\end{array}$ & $\begin{array}{c}\text { Caspase activation } \\
\text { Up-regulation of Bax } \\
\text { Down-regulation of Bcl-2 and Bcl-XL }\end{array}$ & $\begin{array}{c}\text { Food in general } \\
\text { Crustaceans } \\
\text { Mushrooms } \\
\text { [289-292] }\end{array}$ \\
\hline FATTY ACIDS & $\begin{array}{c}\text { Polyunsaturated fatty acids (PUFA) } \\
\text { Omega-3 acids } \\
\text { Docosahexaenoic acid (DHA), } \\
\text { eicosapentaenoic acid (EPA) } \\
\text { Conjugated linoleic acid (CLA) } \\
\alpha \text {-linolenic acid (ALA) }\end{array}$ & $\begin{array}{c}\text { Mitochondrial pathway } \\
\text { Caspase activation } \\
\text { Up-regulation of Bax } \\
\text { Down-regulation of Bcl-2 and Bcl-XL }\end{array}$ & $\begin{array}{c}\text { Vegetable oils } \\
\text { Fish oils } \\
\text { Flaxseed oil } \\
\text { Canola, soy, perilla and walnut oils } \\
\text { Beef } \\
\text { Cheese, Whole milk } \\
{[293-296]}\end{array}$ \\
\hline GLYCOPROTEINS & Lactoferrin & $\begin{array}{c}\text { Caspase activation } \\
\text { Up-regulation of Bax } \\
\text { Down-regulation of Bcl-2 and Bcl-XL }\end{array}$ & $\begin{array}{c}\text { Milk } \\
{[297,298]}\end{array}$ \\
\hline
\end{tabular}

on its concentration, target molecule(s) and environmental conditions (e.g. free radical sources available) [252]. The prooxidant activity (ROS production) may be a mechanism for induction of apoptosis by polyphenols, preventing tumor growth [22,24,25,87] (See Tables 1-3).

Studies have also addressed the pro-apoptotic activities of other dietary components. Examples of such dietary compounds include Phase 2 enzyme inducers (some of them are polyphenols), butyric acid (high fiber diets), monoterpenes (citrus oil and mint), omega-3 fatty acids (fish oil) and sphingolipids (dairy and soy products) which were found to induce apoptosis in cancer cell lines and to protect from cancer in animal models [20]. A very recent review of studies carried out both in cancer cell lines and in animal models of cancer revealed pro-apoptotic effects of different polyunsaturated fatty acids (PUFAs) found in dairy products, meat, fish, vegetable seeds and oils, known to affect the incidence and progression of cancer [253]. It is also becoming clear that naturally occurring organosulfur compounds, namely diallyl sulphide, diallyl disulfide and dially trisulfide, from dietary intake of Allium vegetables (e.g. garlic, onions) can suppress proliferation of cancer cells in culture and inhibit growth of transplanted tumor xenografts by inducing apoptosis and/or causing cell cycle arrest [254]. $\beta$-carotene, a carotenoid existent in orange vegetables, also presents growth inhibitory and pro-apoptotic effects in various tumor cells from human colon, breast and prostate cancers and leukaemia cells, whereas normal cells are largely resistant to apoptosis [255]. There is evidence showing that vitamin E [256], selenium [257] and vitamin C [258] also selectively induce apoptosis in tumor without affecting normal cells. Recently, extracts of tomatoes and the associated phytochemical lycopene have been shown to induce apoptosis in human prostate cancer cells [259] and also in clinical trials [260].

As for polyphenols, several other antioxidants such as vitamin $\mathrm{C}$ or $\beta$-carotene can act as pro-oxidants (causing oxidative stress and apoptosis) depending on the cellular redox status [28,261].

Table 4 show representative studies using different dietary components which probed to induce apoptosis, their trivial names, dietary sources and apoptosis induction markers studied.

\section{SUMMARY AND PERSPECTIVES}

The pathogenesis of many diseases, including cancer has been associated with aberrantly regulated apoptosis [20,26,67,68,299]. The synergic combination of an undesirable proliferative stimulus and an associated defect in the apoptotic pathway(s) seems universal in cancer [65, 67-70]. Dietary habits are estimated to contribute to, at least, one third of all human cancers [300], showing that dietary components can exacerbate or interfere with carcinogenesis. Apoptosis is likely to be a crucial mechanism in the chemopreventive properties associated with several dietary factors [20], by eliminating potentially deleterious cells.

In addition to the conventional therapeutic agents, numerous dietary components and micronutrients are emerging, with considerable potential for hindering in vivo deleterious oxidative processes and inducing apoptosis of cancerous or pre-cancerous cells [86,300-302], therefore being considered as promising chemopreventive agents. A range of dietary compounds can modulate apoptosis and those with pro-apoptotic properties showed beneficial effects in animal and in vitro studies by eliminating cancerous cells $[20,28,84,86]$. Moreover, some have also showed beneficial effects in clinical trials [85]

Apoptosis, however, is a very complex process with numerous specific targets within each arm of apoptotic pathway targets. Nevertheless, it is very encouraging that single bioactive dietary agents can directly and indirectly influence most of myriad targets within apoptosis. Additionally, many of these dietary agents appear to exhibit some degree of specificity for neoplastic, while sparing normal cells. Furthermore, the protective effects of single agents can be potentiated/synergized by other dietary factors suggesting the possibility of combinatorial approaches for chemoprevention. While dietary interventions seem encouraging for devising new chemopreventive strategies, there are several issues remaining to be fully understood: the dose of each agent, duration of exposure, relative bioavailability of each dietary compound and potentially adverse side effects and/or interactions.

Further research is definitively needed to identify phytochemical-specific molecular targets and to understand the underlying molecular mechanisms of the huge number of already 
recognized bioactive dietary chemopreventive agents. The potential benefits of cancer chemoprevention appear promising given the results obtained in clinical trials, animal carcinogenesis models and in vitro studies. Collectively, these considerations support the need for chemoprevention to manage cancer both at present and in the future.

Since apoptosis can be at the origin of tumorigenesis and of resistance to chemotherapy, it is important to advance our knowledge of this process of programmed cell death and, therefore, find agents that can selectively manipulate specific steps, namely targetting mitochondria-mediated apoptosis [82,87].

As implied above, chemoprevention is not a simple issue, and success may not come swiftly. However, for individuals at high risk of cancer (and possibly the general population in the future), chemoprevention has the potential of providing an important means for cancer risk reduction.

In the last decade, dietary polyphenols, which are the most abundant antioxidants present in a normal human diet, have received increasing interest from researchers, food manufacturers and also consumers as one of the most promising groups of dietary chemopreventive agents. Functional foods have been recently introduced in the market as a group of products containing high amounts of one or more compounds with particular biochemical functions (bioactive components), considered beneficial to the human health. Indeed, polyphenols are anti-oxidant agents, capable of protecting tissues against deleterious oxidative stress (along with other dietary antioxidants as vitamins $\mathrm{C}$ and $\mathrm{E}$, and carotenoids) and are able to induce apoptosis in damaged cells. Moreover, despite their unquestionable beneficial effects, consumption of phenolic compounds as dietary supplements should be followed with care, since their activity is strongly dose-dependent and they can lead to toxic interactions at high concentrations. Although looking at the different anti-oxidant and pro-oxidant properties towards normal and pre-cancerous cells, the production of ROS is now considered one of the main mechanisms for chemopreventive agents as apoptosis inducers [87]. Critical thinking on the use of functional foods is thus essential, since they can fail to be beneficious, under certain conditions, and a real pharmacological approach is required in order to consolidate their implementation.

As with other dietary components, much evidence of the chemopreventive activities of polyphenols came from in vitro or animal studies [25]. Information on their clinical properties, which might help to evaluate their efficacy as human cancer chemopreventive agents, is still scarce [303]. The present available epidemiologic studies on the effects of polyphenols focused in ingestion of flavonoids and lignans showed no decrease in risk of cancer except, possibly, for lung cancer [21]. In fact, the careful design of epidemiological prospective studies on the effects of polyphenols and other dietary components in chemoprevention/ human health, resembling the large epidemiological intervention studies performed for other anti-oxidants (namely $\beta$-carotene) [304] is urgently needed.

This should lead to the establishment of dietary recommendations, supplementation aimed at particular population groups, namely those presenting enhanced cancer risk due to environmental, behavioural or genetic factors.

$\begin{array}{lll}\text { ABBREVIATIONS } & \\ \text { AIF } & = & \text { Apoptosis inducing factor } \\ \text { Akt } & = & \text { Protein kinase B } \\ \text { AP-1 } & \text { Activator protein-1 } \\ \text { Apaf-1 } & = & \text { Apoptosis-activating factor 1 } \\ \text { Apo2L TRAIL } & = & \text { Tumor necrosis factor-related apoptosis- } \\ & & \text { inducing ligand }\end{array}$

Apo3L

CAD

CAPE

c-myc

DD

DISC

DR

EGCG

FADD

FasL

FasR

GFR

HtrA2/Omi

$\mathrm{HeLa}$

Hep2

HPV

IAP

ICAD

IкB

MAP

MAPK

MCF-7

MOLT-4

MPT

NF- $\kappa \mathrm{B}$

NOXA

PARP

PC-9

PI3K

PK

PUMA

RNS

ROS

Smac/DIABLO

TNF

TNFR

TRADD

\section{REFERENCES}

References 305-307 are related articles recently published.

[1] Stewart BW, Kleihues P. Eds. World Cancer Report, Internacional Agency for Research on Cancer, World Health Organization, 2003 (ISBN 9283204115).

[2] Everitt AV, Hilmer SN, Brand-Miller JC, Jamieson HA, Truswell AS, Sharma AP, et al. Dietary approaches that delay age-related diseases. Clin IntervAging 2006; 1: 11-31.

[3] Chiuve SE, Willet WC. The 2005 Food Guide Pyramid: an opportunity lost? Nat Clin Pract Cardiovasc Med 2007; 4: 610-20.

[4] Riboli E, Norat T. Epidemiologic evidence of the protective effect of fruit and vegetables on cancer risk. Am J Clin Nutr 2003; 78: 559S-69. 
[5] Gonzalez CA, Riboli E. Diet and cancer prevention: where we are, where we are going. Nutr Cancer 2006; 56: 225-31.

[6] Crawford M, Galli C, Visioli F, Renaud S, Simopoulos AP, Spector AA. Role of plant-derived omega-3 fatty acids in human nutrition. Ann Nutr Metab 2000; 44: 263-5.

[7] Berquin IM, Min Y, Wu R, Wu J, Perry D, Cline, JM, et al. Modulation of prostate cancer genetic risk by omega-3 and omega6 fatty acids. J Clin Invest 2007; 117: 1866-75.

[8] Gago-Dominguez M, Yuan JM, Sun CL, Lee HP, Yu MC. Opposing effects of dietary n-3 and n-6 fatty acids on mammary carcinogenesis: The Singapore Chinese Health Study. Br J Cancer 2003; 89: 1686-92.

[9] Schulze MB, Schulz M, Heidemann C, Schienkiewitz A, Hoffmann $\mathrm{K}$, Boeing $\mathrm{H}$. Fiber and magnesium intake and incidence of type 2 diabetes: a prospective study and meta-analysis. Arch Intern Med 2007; 167: 956-65.

[10] Park Y, Hunter DJ, Spiegelman D, Bergkvist L, Berrino F, van den Brandt PA, et al. Dietary fiber intake and risk of colorectal cancer: a pooled analysis of prospective cohort studies. JAMA 2005; 294 : 2849-57.

[11] Joshipura KJ, Hu FB, Manson JE, Stampfer MJ, Rimm EB, Speizer $\mathrm{FE}$, et al. The effect of fruit and vegetable intake on risk for coronary heart disease. Ann Intern Med 2001; 134: 1106-14.

[12] Gillman MW, Cupples LA, Gagnon D, Posner BM, Ellison RC, Castelli WP, et al. Protective effect of fruits and vegetables on development of stroke in men. JAMA 1995; 273: 1113-7.

[13] Block G, Patterson B, Subar A. Fruit, vegetables, and cancer prevention: a review of the epidemiological evidence. Nutr Cancer 1992; 18: 1-29.

[14] Pavia M, Pileggi C, Nobile CG, Angelillo IF. Association between fruit and vegetable consumption and oral cancer: a meta-analysis of observational studies. Am J Clin Nutr 2006; 83: 1126-34.

[15] García-Closas R, García-Closas M, Kogevinas M, Malats N, Silverman D, Serra C, et al. Food, nutrient and heterocyclic amine intake and the risk of bladder cancer. Eur J Cancer 2007; 43: 173140.

[16] Faramawi MF, Johnson E, Fry MW, Sall M, Zhou Y. Consumption of different types of meat and the risk of renal cancer: meta-analysis of case-control studies. Cancer Causes Control 2007; 18: 125-33.

[17] Steinmaus CM, Nuñez S, Smith AH. Diet and bladder cancer: a meta-analysis of six dietary variables. Am J Epidemiol 2000; 151: 693-702.

[18] Polesel J, Talamini R, Montella M, MasoLD, Crovatto M, Parpinel $\mathrm{M}$, et al. Nutrients intake and the risk of hepatocellular carcinoma in Italy. Eur J Cancer 2007; 43: 2381-7.

[19] Connelly-Frost A, Poole C, Satia JA, Kupper LL, Millikan RC, Sandler RS. Selenium, apoptosis, and colorectal adenomas. Cancer Epidemiol Biomarkers Prev 2006; 15: 486-93.

[20] Watson WH, Cai J, Jones DP. Diet and Apoptosis. Annu Rev Nutr 2000; 20: 485-505.

[21] Arts ICW, Hollman PCH. Polyphenols and disease risk in epidemiologic studies. Am J Clin Nutr 2005; 81: 317S-25

[22] Nichenametla SN, Taruscio TG, Barney DL, Exon JH. A review of the effects and mechanisms of polyphenolics in cancer. Crit Rev Food Sci Nutr 2006; 46: 161-83.

[23] Ramos S. Cancer chemoprevention and chemotherapy: dietary polyphenols and signalling pathways. Mol Nutr Food Res 2008; 52: 507-26.

[24] Lambert JD, Hong J, Yang G, Liao J, Yang CS. Inhibition of carcinogenesis by polyphenols: evidence from laboratory investigations. Am J Clin Nutr 2005; 81: 284S-91.

[25] Fresco P, Borges F, Diniz C, Marques MP. New insights on the anticancer properties of dietary polyphenols. Med Res Rev 2006; 26: 747-66.

[26] Saikumar P, Dong Z, Mikhailov V, Denton M, Weinberg JM, Venkatachalam MA. Apoptosis: definition, mechanism, and relevance to disease. Am J Med 1999; 107: 489-506.

[27] Sun SY, Hail NJr, Lotan R. Apoptosis as a novel target for cancer chemoprevention. J Natl Cancer Inst 2004; 96: 662-72.

[28] Martin KR. Targeting apoptosis with dietary bioactive agents. Exp Biol Med 2006: 231, 117-29.

[29] Kerr JF, Wyllie AH, Currie AR. Apoptosis: a basic biological phenomenon with wide-ranging implications in tissue kinetics. $\mathrm{Br} \mathbf{J}$ Cancer 1972; 26: 239-57.
[30] Kurosaka K, Takahashi M, Watanabe N, Kobayashi Y. Silent cleanup of very early apoptotic cells by macrophages. J Immunol 2003; 171: 4672-9.

[31] Elmore, S. Apoptosis: a review of programmed cell death. Toxicol Pathol 2007; 35: 495-516.

[32] Trump BF, Berezesky IK, Chang SH, Phelps PC. The pathways of cell death: oncosis, apoptosis, and necrosis. Toxicol Pathol 1997; 25: 82-8.

[33] Denault JB, Salvesen GS. Caspases: keys in the ignition of cell death. Chem Rev 2002; 102: 4489-500

[34] Wang ZB, Liu YQ, Cui YF. Pathways to caspase activation. Cell Biol Int 2005; 29: 489-96.

[35] Rai NK, Tripathi K, Sharma D, Shukla VK. Apoptosis: a basic physiologic process in wound healing. Int J Low Extrem Wounds 2005; 4: 138-44.

[36] Martinvalet D, Zhu P, Lieberman J. Granzyme A induces caspaseindependent mitochondrial damage, a required first step for apoptosis. Immunity 2005; 22: 355-70.

[37] Igney FH, Krammer PH. Death and anti-death: tumour resistance to apoptosis. Nat Rev Cancer 2002; 2: 277-88.

[38] Locksley RM, Killeen N, Lenardo MJ. The TNF and TNF receptor superfamilies: integrating mammalian biology. Cell 2001; 104: 487501.

[39] Rowinsky EK. Targeted induction of apoptosis in cancer management: the emerging role of tumor necrosis factor-related apoptosis-inducing ligand receptor activating agents. J Clin Oncol 2005, 23: 9394-407.

[40] Mérino D, Lalaoui N, Morizot A, Solary E, Micheau O. TRAIL in cancer therapy: present and future challenges. Expert Opin Ther Targets 2007; 11: 1299-314.

[41] Schaefer U, Voloshanenko O, Willen D, Walczak H. TRAIL: a multifunctional cytokine. Front Biosci 2007; 12: 3813-24

[42] Falschlehner C, Emmerich CH, Gerlach B, Walczak H. TRAIL signalling: decisions between life and death. In J Biochem Cell Biol 2007; 39: 1462-75.

[43] Medema JP, Scaffidi C, Kischkel FC, Shevchenko A, Mann M, Krammer PH, et al. FLICE is activated by association with the CD95 death-inducing signaling complex (DISC). EMBO J 1997; 16: 2794-804.

[44] Anguiano-Hernandez YM, Chartier A, Huerta S. Smac/DIABLO and colon cancer. Anticancer Agents Med Chem 2007; 7: 467-73.

[45] Schimmer AD. Inhibitor of apoptosis proteins: translating basic knowledge into clinical practice. Cancer Res 2004; 64: 7183-90.

[46] Millan A, Huerta S. Apoptosis-Inducing Factor and Colon Cancer. J Surg Res 2009; 151: 163-70.

[47] Joza N, Susin SA, Daugas E, Stanford WL, Cho SK, Li CY, et al. Essential role of the mitochondrial apoptosis-inducing factor in programmed cell death. Nature, 2001; 410: 549-54.

[48] Widlak P, Garrard WT. Discovery, regulation, and action of the major apoptotic nucleases DFF40/CAD and endonuclease G. J Cell Biochem 2005; 94: 1078-87.

[49] Inohara N, Koseki $\mathrm{T}$, Chen $\mathrm{S}$, Benedict MA, Núnez G. Identification of regulatory and catalytic domains in the apoptosis nuclease DFF40/CAD. J Biol Chem 1999; 274: 270-4.

[50] Cory S, Adams JM. The Bcl2 family: regulators of the cellular lifeor-death switch. Nat Rev Cancer 2002; 2: 647-56.

[51] Thomadaki H, Scorilas A. BCL2 family of apoptosis related genes: functions and clinical implications in cancer. Crit Ver Clin Lab Sci 2006; 43: 1-67.

[52] Hockenbery D, Nunez G, Milliman C, Schreiber RD, Korsmeyer SJ. Bcl-2 is an inner mitochondrial membrane protein that blocks programmed cell death. Nature 1990; 348: 334-6.

[53] Krajewski S, Tanaka S, Takayama S, Schibler MJ, Fenton W, Reed JC. Investigation of the subcellular distribution of the bcl-2 oncoprotein: residence in the nuclear envelope, endoplasmic reticulum, and outer mitochondrial membranes. Cancer Res 1993; 53: 4701-14.

[54] Kluck RM, Bossy-Wetzel E, Green DR, Newmeyer DD. The release of cytochrome $\mathrm{c}$ from mitochondria: a primary site for Bcl-2 regulation of apoptosis. Science 1997; 275: 1132-36.

[55] Yang J, Liu X, Bhalla K, Kim CN, Ibrado AM, Cai J, et al. Prevention of apoptosis by Bcl-2: release of cytochrome $\mathrm{c}$ from mitochondria blocked. Science 1997; 275: 1129-32.

[56] Kothakota S, Azuma T, Reinhard C, Klippel A, Tang J, Chu K, et al. Caspase-3-generated fragment of gelsolin: effector of morphological change in apoptosis. Science 1997; 278: 294-8. 
[57] Ghobrial IM, Witzig TE, Adjei AA. Targeting apoptosis pathways in cancer therapy. CA Cancer J Clin 2005; 55: 178-194.

[58] Benchimol S. p53-dependent pathways of apoptosis. Cell Death Differ 2001; 8: 1049-51.

[59] Maldonado V, Meléndez-Zajgla J, Ortega A. Modulation of NFkappa B, and Bcl-2 in apoptosis induced by cisplatin in HeLa cells. Mutat Res 1997; 381: 67-75.

[60] Kühnel F, Zender L, Paul Y, Tietze MK, Trautwein C, Manns M, et al. NF-kB mediates apoptosis through transcriptional activation of Fas (CD95) in adenoviral hepatitis. J Biol Chem 2000; 275: 6421-7.

[61] Myung J, Kim KB, Crew CM. The ubiquitin-proteasome pathway and proteasome inhibitors. Med Res Rev 2001; 21; 245-73.

[62] Adams J, Palombella VJ, Elliot PJ. Proteasome inhibition: a new strategy in cancer treatment. Invest New Drugs 2000; 18: 109-21.

[63] Cantley LC. The phosphoinositide 3-kinase pathway. Science 2002; 296: 1655-57.

[64] Kerr JF, Winterford CM, Harmon BV. Apoptosis. Its significance in cancer and cancer therapy. Cancer 1994; 73: 2013-26.

[65] Wyllie AH, Bellamy CO, Bubb VJ, Clarke AR, Corbet S, Curtis L, et al. Apoptosis and carcinogenesis. Br J Cancer 1999; 80: 34-7.

[66] Wyllie A. Apoptosis. Clues in the p53 murder mystery. Nature 1997; 389: 237-238.

[67] Reed JC. Dysregulation of apoptosis in cancer. J Clin. Oncol 1999; 17: 2941-53.

[68] Zhivotovsky B, Orrenius S. Carcinogenesis and apoptosis: paradigms and paradoxes. Carcinogenesis 2006; 27: 1939-45.

[69] Thompson CB. Apoptosis in the pathogenesis and treatment of disease. Science 1995; 267: 1456-62.

[70] Hanahan D, Weinberg RA. The hallmarks of cancer. Cell 2000; 100: 57-70.

[71] Hueber AO, Evan GI. Traps to catch unwary oncogenes. Trends Genet 1998; 14: 364-7.

[72] Harris AL. Hypoxia -- a key regulatory factor in tumour growth. Nat Rev Cancer 2002; 2: 38-47.

[73] Wright SC, Zhong J, Larrick JW. Inhibition of apoptosis as a mechanism of tumor promotion FASEB J 1994; 8: 654-60.

[74] Roth W, Reed JC. Apoptosis and cancer: when BAX is TRAILing away. Nat Med 2002; 8: 216-218.

[75] Miyashita T, Krajewski S, Krajewska M, Wang HG, Lin HK, Liebermann DA, et al. Tumor suppressor $\mathrm{p} 53$ is a regulator of bcl-2 and bax gene expression in vitro and in vivo. Oncogene 1994; 9: 1799-805.

[76] Wang XW. Role of p53 and apoptosis in carcinogenesis. Anticancer Res 1999; 19: 4759-71.

[77] Bourdon JC. p53 and its isoforms in cancer. Br J Cancer 2007; 97: 277-282.

[78] Riboli E, Norat T. Cancer prevention and diet: opportunities in Europe. Public Health Nutr 2001; 4: 475-84.

[79] Key TJ, Schatzkin A, Willet WC, Allen NE, Spencer EA, Travis RC. Diet, nutrition and the prevention of cancer. Public Health Nutr 2004; 7: 187-200.

[80] Gonzalez CA. Nutrition and Cancer: the current epidemiological evidence. Br J Nutr 2006; 96: S42-S45.

[81] Stan SD, Kar S, Stoner G, Singh S. Bioactive food components and cancer risk reduction. J Cell Biochem 2008; 104: 339-56.

[82] Hail N Jr. Mitochondria: A novel target for the chemoprevention of cancer. Apoptosis 2005; 10: 687-705.

[83] Bouchier-Hayes L, Lartigue L, Newmeyer DD. Mitochondria: pharmacological manipulation of cell death. J Clin Invest 2005; 115: 2640-7.

[84] Kelloff GJ, Sigman CC, Greenwald P. Cancer Chemoprevention: Progress and Promise. Eur J Cancer 1999; 35: 2031-8.

[85] Kakizoe T. Chemoprevention of cancer--focusing on clinical trials. Jpn J Clin Oncol 2003; 33: 421-42.

[86] Kelloff GJ, Crowell JA, Steele VE, Lubet RA, Malone WA, Boone $\mathrm{CW}$, et al. Cancer Chemoprevention: Development of Diet-derived Chemopreventive Agents. J Nutr 2000; 130: 467S-471S.

[87] Hail Jr. N, Cortes M, Darke EN, Spalholz JE. Cancer chemoprevention: A radical perspective. Free Rad Biol Med 2008; 45; 97-110.

[88] Manach C, Williamson G, Morand C, Sealbert A, Rémésy C. Bioavailability and Bioefficacy of Polyphenols in Humans: I. Review of 97 Bioavailability Studies. Am J Clin Nutr 2005; 81: 230S-242S.
[89] Scalbert A, Manach C, Morand C, Rémésy C, Jiménez L. Dietary polyphenols and the prevention of diseases. Crit Rev Food Sci Nutr 2005; 45: 287-306.

[90] Lepley DM, Li B, Birt DF, Pelling JC. The Chemopreventive Flavonoid Apigenin Induces G2/M Arrest in Keratinocytes. Carcinogenesis 1996; 17: 2367-75.

[91] Skaper SD, Fabris M, Ferrari V, Carbonare MD, Leon A. Quercetin Protects Cutaneous Tissue-associated Cell Types Including Sensory Neurons from Oxidative Stress Induced by Glutathione Depletion: Cooperative Effects of Ascorbic Acid. Free Radic Biol Med 1997; 22: 669-78.

[92] Agullo G, Gamet-Payrastre L, Manenti S, Viala C, Rémésy C, Chap $\mathrm{H}$, et al. Relationship Between Flavonoid Structure and Inhibition of Phosphatidylinositol-3-kinase and Protein Kinase C Inhibiton. Biochem Pharmacol 1997; 53: 1649-57.

[93] Sergediene E, Jonsson K, Szymusiak H, Tyrakowska B, Rietjens ICM, Cenas N. Prooxidant Toxicity of Polyphenolic Antioxidants to HL-60 Cells: Description of Quantitative Structure-activity Relationships. FEBS Lett 1999; 462: 392-6.

[94] Yang CS., Maliakal P, Meng X. Inhibition of carcinogenesis by tea. Ann Rev Pharmacol Toxicol 2002; 42: 25-54.

[95] Bianco A, Muzzalupo I, Piperno A, Romeo G, Uccella N. Bioactive Derivatives of Oleuropein from Olive Fruits. J Agric Food Chem 1999; 47: 3531-4.

[96] Trichopoulou A, Lagiou P, Pappas AM. Mediterranean Diet: Are Antioxidants Central to its benefits? In: Pappas AM Ed, Antioxidant Status, Diet, Nutrition and Health, Boca Raton, Washington CRC Press, 1999; 107-118.

[97] Hollman PCH, Katan MB. Dietary Flavonoids: Intake, Health Effects and Bioavailability. Food \& Chem Toxicology 1999; 37: 937-42.

[98] Bianco A, Uccella N. Biophenolic Components of Olives. Food Res Int 2000; 33: 475-85.

[99] Visioli F, Galli C. Biological Properties of Olive Oil Phytochemicals. Crit. Rev. Food Sci Nutr 2002; 42: 209-21.

[100] Scalbert A, Williamson G. Dietary Intake and Bioavailability of Polyphenols. J Nutr 2000; 130: 2073S-2085S.

[101] Higdon JV, Frei B. Tea catechins and polyphenols: health effects, metabolism, and antioxidant functions. Crit Rev Food Sci Nutr 2003; 43: 89-143.

[102] Nijveldt RJ, van Nood E, van Hoorn DE, Boelens PG, van Norren $\mathrm{K}$, van Leeuwen PA. Flavonoids: a review of probable mechanisms of action and potential applications. Am J Clin Nutr 2001; 74: 41825.

[103] Fotsis T, Pepper MS, Aktas E, Breit S, Rasku S, Adlercreutz H, et al. Flavonoids, dietary-derived inhibitors of cell proliferation and in vitro angiogenesis. Cancer Res 1997; 57: 2916-21.

[104] Veluri R, Singh RP, Liu Z, Thompson JA, Agarwal R, Agarwal C. Fractionation of grape seed extract and identification of gallic acid as one of the major active constituents causing growth inhibition and apoptotic death of DU145 human prostate carcinoma cells. Carcinogenesis 2006; 27: 1445-53.

[105] Agarwal C, Tyagi A, Agarwal R. Gallic acid causes inactivating phosphorylation of cdc25A/cdc25C-cdc2 via ATM-Chk2 activation, leading to cell cycle arrest, and induces apoptosis in human prostate carcinoma DU145 cells. Mol Cancer Ther 2006; 12: 3294-302.

[106] Kampa M, Alexaki VI, Notas G, Nifli AP, Nistikaki A, Hatzoglou A, et al. Antiproliferative and apoptotic effects of selective phenolic acids on T47D human breast cancer cells: potential mechanisms of action. Breast Cancer Res 2004; 6: R63-R74.

[107] He YJ, Liu BH, Xiang DB, Qiao ZY, Fu T, He YH. Inhibitory effect of caffeic acid phenethyl ester on the growth of SW480 colorectal tumor cells involves $\beta$-catenin associated signaling pathway down-regulation. World J Gastroenterol 2006; 21: 4981-5.

[108] McEleny K, Coffey R, Morrissey C, Fitzpatrick JM, Watson RW. Caffeic acid phenethyl ester-induced PC-3 cell apoptosis is caspasedependent and mediated through the loss of inhibitors of apoptosis proteins. BJU Int 2004; 94: 402-6.

[109] Balasubramanian S, Eckert RL. Keratinocyte proliferation, differentiation, and apoptosis-differential mechanisms of regulation by curcumin, EGCG and apigenin. Toxicol Appl Pharmacol 2007; 224: 214-9.

[110] Shi M, Cai Q, Yao L, Mao Y, Ming Y. Ouyang G. Antiproliferation and apoptosis induced by curcumin in human ovarian cancer cells. Cell Biol Int 2006; 30: 221-6. 
[111] Singh S, Khar A. Biological effects of curcumin and its role in cancer chemoprevention and therapy. Anticancer Agents Med Chem 2006; 6: 259-70.

[112] Karunagaran D, Rashmi R, Kumar TR. Induction of apoptosis by curcumin and its implications for cancer therapy. Curr Cancer Drug Targets 2005; 5: 117-129.

[113] Sanchez AM, Malagarie-Cazenave S, Olea N, Vara D, Chiloeches A, Díaz-Laviada I. Apoptosis induced by capsaicin in prostate PC-3 cells involves ceramide accumulation, neutral sphingomyelinase, and JNK activation. Apoptosis 2007; 12: 2013-24.

[114] Kim YM, Hwang JT, Kwak DW, Lee YK, Park OJ. Involvement of AMPK signaling cascade in capsaicin-induced apoptosis of HT-29 colon cancer cells. Ann N Y Acad Sci 2007; 1095: 496-503.

[115] Morre DM, Morre DJ. Catechin-vanilloid synergies with potential clinical applications in cancer. Rejuvenation Res 2006; 9: 45-55.

[116] Hsu S, Singh B, Schuster G. Induction of apoptosis in oral cancer cells: Agents and mechanisms for potential therapy and prevention. Oral Oncol 2004; 40: 461-73.

[117] Ishiguro K, Ando T, Maeda O, Ohmiya N, Niwa Y, Kadomatsu K, et al. Ginger ingredients reduce viability of gastric cancer cells via distinct mechanisms. Biochem Biophys Res Commun 2007; 362: 218-23.

[118] Bode AM, Dong Z. Targeting signal transduction pathways by chemopreventive agents. Mutat Res 2004; 555: 33-51.

[119] Keum YS, Kim J, Lee KH, Park, KK, Surh YJ, Lee JM, et al. Induction of apoptosis and caspase-3 activation by chemopreventive [6]-paradol and structurally related compounds in KB cells. Cancer Lett 2002; 177: 41-7.

[120] Ragione FD, Cucciolla V, Borriello A, Pietra VD, Pontoni G, Racioppi L, et al. Hydroxytyrosol, a natural molecule occurring in olive oil, induces cytochrome c-dependent apoptosis. Biochem Biophys Res Commun 2000; 278:733-739.

[121] Fabiani R, De Bartolomeo A, Rosignoli P, Servili M, Montedoro GF, Morozzi G. Cancer chemoprevention by hydroxytyrosol isolated from virgin olive oil through G1 cell cycle arrest and apoptosis. Eur J Cancer Prev 2002; 11: 351-8.

[122] Wolf I, O'Kelly J, Wakimoto N, Nguyen A, Amblard F, Karlan BY, et al. Honokiol, a natural biphenyl, inhibits in vitro and in vivo growth of breast cancer through induction of apoptosis and cell cycle arrest. Int J Oncol 2007; 30: 1529-1537.

[123] Ahn KS, Sethi G, Shishodia S, Sung B, Arbiser JL, Aggarwal BB. Honokiol potentiates apoptosis, suppresses osteoclastogenesis, and inhibits invasion through modulation of NF- $\mathrm{kB}$ activation pathway. Mol Cancer Res 2006; 4: 621-33.

[124] Cecchinato V, Chiaramonte R, Nizzardo M, Cristofaro B, Basile A, Sherbet GV, et al. Resveratrol-induced apoptosis in human T-cell acute lymphoblastic leukaemia MOLT-4 cells. Biochem Pharmacol 2007; 74: 1568-74

[125] Van Ginkel PR, Sareen D, Subramanian L, Walker Q, Darjatmoko SR, Lindstrom MJ, et al. Resveratrol inhibits tumor growth of human neuroblastoma and mediates apoptosis by directly targeting mitochondria. Clin Cancer Res 2007; 13: 5162-9.

[126] Shankar S, Singh G, Srivastava R.K. Chemoprevention by resveratrol: molecular mechanisms and therapeutic potential. Front Biosci 2007; 12: 4839-4854

[127] Gill C, Walsh SE, Morrissey C, Fitzpatrick JM, Watson RW. Resveratrol sensitizes androgen independent prostate cancer cells to death-receptor mediated apoptosis through multiple mechanisms. Prostate 2007; 67: 1641-53.

[128] Lion CJ, Matthews CS, Stevens MFG, Westwell AD. Synthesis, antitumor evaluation, and apoptosis-inducing activity of hydroxylated (E)-stilbenes. J Med Chem 2005; 48: 1292-5.

[129] Pozo-Guisado E, Merino JM, Mulero-Navarro S, Lorenzo-Benayas MJ, Centeno F, Alvarez-Barrientos A, et al. Resveratrol-induced apoptosis in MCF-7 human breast cancer cells involves a caspaseindependent mechanism with downregulation of Bcl-2 and NF- $\mathrm{kB}$. Int J Cancer 2005; 115: 74-84

[130] Pan L, Becker H, Gerhäuser C. Xanthohumol induces apoptosis in cultured 40-16 human colon cancer cells by activation of the death receptor- and mitochondrial pathway. Mol Nutr Food Res 2005; 49: 837-43.

[131] Colgate EC, Miranda CL, Stevens JF, Bray TM, Ho E. Xanthohumol, a prenylflavonoid derived from hops induces apoptosis and inhibits NF-kB activation in prostate epithelial cells. Cancer Lett 2007; 246: 201-9.
[132] Go ML, Wu X, Liu XL. Chalcones: An update on cytotoxic and chemoprotective properties. Curr Med Chem 2005; 12: 481-499.

[133] Nam S, Smith DM, Dou QP. Tannic acid potently inhibits tumor cell proteasome activity, increases p27 and bax expression, and induces G1 arrest and apoptosis. Cancer Epidemiol. Biomarkers Prev 2001; 10: 1083-8

[134] Kuo PL, Hsu YL, Lin TC, Tzeng WS, Chen YY, Lin CC. Rugosin $\mathrm{E}$, an ellagitannin, inhibits MDA-MB-231 human breast cancer cell proliferation and induces apoptosis by inhibiting NF- $\mathrm{KB}$ signaling pathway. Cancer Lett 2007; 248: 280-91.

[135] Larrosa M, Tomás-Barberan FA, Espín JC. The dietary hydrolysable tannin punicalagin releases ellagic acid that induces apoptosis in human colon adenocarcinoma Caco-2 cells by using the mitochondrial pathway. J Nutr Biochem 2006; 17: 611-25.

[136] Kim YH, Lee YJ. TRAIL apoptosis is enhanced by quercetin through akt dephosphorylation. J Cell Biochem 2007; 100: 9981009 .

[137] Haghiac M, Walle T. Quercetin induces necrosis and apoptosis in SCC-9 oral cancer cells. Nutr Cancer 2005; 53: 220-31.

[138] Psahoulia FH, Drosopoulos KG, Doubravska L, Andera L, Pintzas A. Quercetin enhances TRAIL-mediated apoptosis in colon cancer cells by inducing the accumulation of death receptors in lipid rafts. Mol Cancer Ther 2007; 6: 2591-9.

[139] Vijayababu MR, Kanagaraj P, Arunkumar A, Ilangovan R, Dharmarajan, A, Arunakaran J. Quercetin induces p53-independent apoptosis in human prostate cancer cells by modulating Bcl-2related proteins: A possible mediation by IGFBP-3. Oncol Res 2006; 16: 67-74.

[140] Granado-Serrano AB, Martín MA, Bravo L, Goya L, Ramos S. Quercetin induces apoptosis via caspase activation, regulation of bcl-2, and inhibition of PI-3-kinase/Akt and ERK pathways in a human hepatoma cell line (HepG2). J Nutr 2006; 136: 2715-21.

[141] Ma G, Yang C, Qu Y, Wei H, Zhang T, Zhang N. The flavonoid component isorhamnetin in vitro inhibits proliferation and induces apoptosis in Eca-109 cells. Chem Biol Interact 2007; 167: 153-60.

[142] Sharma V, Joseph C, Ghosh S, Agarwal A, Mishra MK, Sen E. Kaempferol induces apoptosis in glioblastoma cells through oxidative stress. Mol. Cancer Ther 2007; 6: 2544-53.

[143] Horinaka M, Yoshida T, Shiraishi T, Nakata S, Wakada M, Sakai $\mathrm{T}$. The dietary flavonoid apigenin sensitizes malignant tumor cells to tumor necrosis factor-related apoptosis-inducing ligand. Mol Cancer Ther 2006; 5: 945-51.

[144] Khan TH, Sultana S. Apigenin induces apoptosis in hep G2 cells Possible role of TNF- $\alpha$ and IFN- $\gamma$. Toxicology 2006; 217: 206-212.

[145] Zhang T, Chen, X, Qu L, Wu J, Cui R, Zhao Y. Chrysin and its phosphate ester inhibit cell proliferation and induce apoptosis in Hela cells. Bioorg Med Chem 2004; 12: 6097-105.

[146] Selvendiran K, Koga H, Ueno T, Yoshida T, Maeyama M, Torimura $\mathrm{T}$, et al. Luteolin promotes degradation in signal transducer and activator of transcription 3 in human hepatoma cells: An implication for the antitumor potential of flavonoids. Cancer Res 2006; 66: 4826-34.

[147] Ju W, Wang X, Shi H, Chen W, Belinsky SA, Lin Y. A critical role of luteolin-induced reactive oxygen species in blockage of tumor necrosis factor-activated nuclear factor- $\mathrm{KB}$ pathway and sensitization of apoptosis in lung cancer cells. Mol Pharmacol 2007; 71: $1381-8$

[148] Shim HY, Park JH, Paik, HD, Nah SY, Kim DS, Han YS. Acacetininduced apoptosis of human breast cancer MCF-7 cells involves caspase cascade, mitochondria-mediated death signaling and SAPK/JNK1/2-c-Jun activation. Mol Cells 2007; 24: 95-104.

[149] Kim MJ, Kim DH, Na HK, Oh TY, Shin CY, Surh YJ. Eupatilin, a pharmacologically active flavone derived from Artemisia plants, induces apoptosis in human gastric cancer (AGS) cells. J Environ Pathol Toxicol Oncol 2005; 24: 261-9

[150] Leung HW, Yang WH, Lai MY, Lin CJ, Lee HZ. Inhibition of 12 lipoxygenase during baicalein-induced human lung nonsmall carcinoma H460 cell apoptosis. Food Chem Toxicol 2007; 45: 40311.

[151] Bektic J, Guggenberger R, Eder IE, Pelzer AE, Berger AP, Bartsch $\mathrm{G}$, et al. Molecular effects of the isoflavonoid genistein in prostate cancer. Clin Prostate Cancer 2005; 4: 124-9.

[152] Chodon D, Banu SM, Padmavathi R, Sakthisekaran D. Inhibition of cell proliferation and induction of apoptosis by genistein in experimental hepatocellular carcinoma. Mol Cell Biochem 2007; 297: 73-80. 
[153] Lo FH, Mak NK, Leung KN. Studies on the anti-tumor activities of the soy isoflavone daidzein on murine neuroblastoma cells. Biomed Pharmacother 2007; 61: 591-5.

[154] Kumar MA, Nair M, Hema PS, Mohan J, Santhoshkumar TR. Pinocembrin triggers Bax-dependent mitochondrial apoptosis in colon cancer cells. Mol Carcinogenesis 2007; 46: 231-41.

[155] Kanno S, Tomizawa A, Ohtake T, Koiwai K, Ujibe M, Ishikawa M. Naringenin-induced apoptosis via activation of NF- $\kappa \mathrm{B}$ and necrosis involving the loss of ATP in human promyeloleukemia HL-60 cells. Toxicol Lett 2006; 166: 131-9.

[156] Brunelli E, Minassi A, Appendino G, Moro L. 8-Prenylnaringenin, inhibits estrogen receptor- $\alpha$ mediated cell growth and induces apoptosis in MCF-7 breast cancer cells. J Steroid Biochem Mol Biol 2007; 107: 140-8.

[157] Huang WJ, Huang CH, Wu CL, Lin JK, Chen YW, Lin CL, et al. Propolin G, a prenylflavanone, isolated from Taiwanese propolis, induces caspase-dependent apoptosis in brain cancer cells. J Agric Food Chem 2007; 55: 7366-76.

[158] Chen CN, Wu CL, Lin JK. Propolin C from propolis induces apoptosis through activating caspases, Bid and cytochrome c release in human melanoma cells. Biochem Pharmacol 2004; 67: 53-66.

[159] Chen CN, Wu CL, Lin JK. Apoptosis of human melanoma cells induced by the novel compounds propolin $\mathrm{A}$ and propolin $\mathrm{B}$ from Taiwenese propolis. Cancer Lett 2007; 245: 218-31

[160] Noda C, He J, Takano T, Tanaka C, Kondo T, Tohyama K, et al. Induction of apoptosis by epigallocatechin-3-gallate in human lymphoblastoid B cells. Biochem Biophys Res Commun 2007; 362: 951-7.

[161] Beltz LA, Bayer DK, Moss AL, Simet IM. Mechanisms of cancer prevention by green and black tea polyphenols. Anticancer Agents Med Chem 2006; 6: 389-406.

[162] Kalra N, Seth K, Prasad S, Singh M, Pant AB, Shukla Y. Theaflavins induced apoptosis of LNCaP cells is mediated through induction of $\mathrm{p} 53$, down-regulation of NF-kB and mitogen-activated protein kinases pathways. Life Sci 2007; 80: 2137-46.

[163] Son YG, Eun HK, Jin YK, Kim SU, Taeg KK, Yoon AR, et al. Silibinin sensitizes human glioma cells to TRAIL-mediated apoptosis via DR5 up-regulation and down-regulation of c-FLIP and survivin. Cancer Res 2007; 67: 8274-84.

[164] Agarwal C, Tyagi A, Kaur M, Agarwal R. Silibinin inhibits constitutive activation of Stat 3 , and causes caspase activation and apoptotic death of human prostate carcinoma DU145 cells. Carcinogenesis 2007; 28: 1463-70.

[165] Zhong X, Zhu Y, Lu Q, Zhang J, Ge Z, Zheng S. Silymarin causes caspases activation and apoptosis in K562 leukemia cells through inactivation of akt pathway. Toxicology 2006; 227: 211-6.

[166] Yeh CT, Yen GC. Induction of apoptosis by the anthocyanidins through regulation of $\mathrm{Bcl}-2$ gene and activation of c-Jun N-terminal kinase cascade in hepatoma cells. J Agric Food Chem 2005; 53: 1740-1749.

[167] Srivastava A, Akoh CC, Fischer J, Krewer G. Effect of anthocyanin fractions from selected cultivars of Georgia-grown blueberries on apoptosis and phase II enzymes. J Agric Food Chem 2007; 55: 3180-5.

[168] Hou DX. Potential mechanisms of cancer chemoprevention by anthocyanins. Curr Mol Med 2003; 3: 149-59.

[169] Borges F, Roleira F, Milhazes N, Santana L, Uriarte E. Simple coumarins and analogues in medicinal chemistry: Occurrence, synthesis and biological activity. Curr Med Chem 2005; 12: 887916.

[170] Jun DY, Kim JS, Park HS, Han CR, Fang Z, Woo MH, et al. Apoptogenic activity of auraptene of Zanthoxylum schinifolium toward human acute leukemia Jurkat T cells is associated with ER stress-mediated caspase- 8 activation that stimulates mitochondriadependent or -independent caspase cascade. Carcinogenesis 2007; 28: 1303-13.

[171] Goel A, Prasad AK, Parmar VS, Ghosh B, Saini N. 7,8-Dihydroxy4-methylcoumarin induces apoptosis of human lung adenocarcinoma cells by ROS-independent mitochondrial pathway through partial inhibition of ERK/MAPK signalling. FEBS Lett 2007; 581:2447-54.

[172] Kang K, Lee HJ, Kim CY, Lee SB, Tunsag J, Batsuren D, et al. The chemopreventive effects of Saussurea salicifolia through induction of apoptosis and phase II detoxification enzyme. Biol Pharm Bull 2007; 30: 2352-9.
[173] Shashi B, Jaswant S, Madhusudana RJ, Kumar SA, Nabi QG. A novel lignan composition from Cedrus deodara induces apoptosis and early nitric oxide generation in human leukemia Molt-4 and HL-60 cells. Nitric Oxide 2006; 14: 72-88.

[174] Webb AL, McCullough ML. Dietary lignans: Potential role in cancer prevention. Nutr Cancer 2005; 51: 117-31.

[175] Mertens-Talcott SU, Lee JH, Percival SS, Talcott ST. Induction of cell death in Caco-2 human colon carcinoma cells by ellagic acid rich fractions from muscadine grapes (Vitis rotundifolia). J Agric Food Chem 2006; 54: 5336-43.

[176] Taraphdar AK, Roy M, Bhattacharya RK. Natural products as inducers of apoptosis: implication for cancer therapy and prevention. Nutr Cancer 2005; 53: 220-31.

[177] Ramos S. Effects of dietary flavonoids on apoptotic pathways related to cancer chemoprevention. J Nutr Biochem 2007; 18: 427 42

[178] Mittal A, Pate MS, Wylie RC, Tollefsbol TO, Katiyar SK. EGCG Down-regulates telomerase in human breast carcinoma MCF-7 cells, leading to suppression of cell viability and induction of apoptosis. Int J Oncol 2004; 24: 703-10.

[179] Kuo PL, Hsu YL, Sung SC, Ni WC, Lin TC, Lin CC. Induction of apoptosis in human breast adenocarcinoma MCF-7 cells by Pterocarnin A from the bark of Pterocarya Stenoptera via the Fasmediated pathway. Anti-Cancer Drugs 2007; 18: 555-62.

[180] Shen S, Chen Y, Hsu F, Lee W. Differential apoptosis-inducing effect of quercetin and its glycosides in human promyeloleukemic HL-60 cells by alternative activation of the caspase- 3 cascade. J Cell Biochem 2003; 89: 1044-1055.

[181] Chen D, Daniel K, Chen M, Kuhn D, Landis-Piwoear K, Dou Q Dietary flavonoids as proteasome inhibitors and apoptosis inducers in human leukaemia cells. Biochem Pharmacol 2005; 69: 1421-32.

[182] Choi JA, Kim JY, Lee JY, Kang CM, Kwon JH. Induction of cell cycle arrest and apoptosis in human breast cancer cells by quercetin. Int J Oncol 2001; 19: 837-44.

[183] Dechsupa S. Quercetin, siamois 1 and siamois 2 induce apoptosis in human breast cancer MDA-MB-435 cells xenograft in vivo. Cancer Biol Ther 2007; 6: 56-61.

[184] Nguyen T, Tran E, Do P, Huynh T, Huynh H. The role of activated MEK-ERK pathway in quercetin-induced growth inhibition and apoptosis in A549 lung cancer cells. Carcinogenesis 2004; 25: 647 59.

[185] Huynh H, Nguyen T, Cahn E, Tran E. Inhibition of ErbB-2 and ErbB-3 expression by quercetin prevents transforming growth factor alpha (TGF-alpha) and epidermal growth factor (EGF) induced human PC-3 prostate cancer cell proliferation. Int J Oncol 2003; 23: 821-9.

[186] Vijayababu M, Kanagaraj P, Arunkumar A, Ilangovan R, Aruldhas M, Arunakaran J. Quercetin-induced growth inhibition and cell death in prostatic carcinoma cells are associated with increase in p21 and hypophosphorylated retinoblastoma proteins expression. J Cancer Res Clin Oncol 2005; 131: 765-71

[187] Van Erik M, Roepman P, van der Lende T, Stierum R, Aarts J, Van Bladeren P. Integrated assessment by multiple gene expression analysis of quercetin bioactivity on anticancer-related mechanisms in colon cancer cells in vitro. Eur J Nutr 2005; 44: 143-56.

[188] Al-Ayyoubi S. Differential apoptosis by gallotannin in human colon cancer cells with distinct p53 status. Mol Carcinogenesis 2007; 46: 176-86.

[189] Stewart JR, Artime MC, O'Brian CA. Resveratrol: a candidate nutritional substance for prostate cancer prevention. J Nutr 2003; 133: 2440S-3S

[190] Xu J, Loo G. Different effects of genistein on molecular markers related to apoptosis in two phenotypically dissimilar breast cancer cell lines. J Cell Biochem 2001; 82: 78-88.

[191] Li Y, Upadhyay S, Bhuiyan M, Sarkar F. Induction of apoptosis in breast cancer cells MDA-MB-231 by genistein. Oncogene 1999 18: 3166-72.

[192] Kumi-Diaka J, Sanderson NA, Hall A. The mediating role of caspase-3 protease in the intracellular mechanism of genisteininduced apoptosis in human prostatic carcinoma cell lines, DU145 and LNCaP. Biol Cell 2000; 92: 595-604.

[193] Li Y, Sarkar F. Inhibition of NF-kB activation in PC3 cells by genistein is mediated via Akt signaling pathway. Clin Cancer Res 2002; 8: 2369-77. 
[194] Yanagihara K, Ito A, Toge T, Numoto M. Antiproliferative effects of isoflavones on human cancer cells lines established from the gastrointestinal tract. Cancer Res 1993; 53: 5815-21.

[195] Lian F, Li Y, Bhuiyan M, Sarkar F. p53-independent apoptosis induced by genistein in lung cancer cells. Nutr Cancer 1999; 33: 125-31.

[196] Alhasan S, Ensley J, Sarkar F. Genistein induced molecular changes in a squamous cell carcinoma of the head and neck cell line. Int $\mathbf{J}$ Oncol 2000; 16: 333-8.

[197] Alhasan S, Pietrasezkiwicz H, Alonso M, Ensley J, Sarkar F. Genistein-induced cell cycle arrest and apoptosis in a head and neck squamous cell carcinoma cell line. Nutr Cancer 1999; 34: 12-9.

[198] Achiwa Y, Hibasami H, Katsuzaki H, Imai K, Komiya T. Inhibitory effects of Persimmon (Diospyros kaki) extract and related polyphenol compounds on growth of human lymphoid leukemia cells. Biosci Biotechnol Biochem 1997; 61: 1099-1101.

[199] Kountouri AM, Kaliora AC, Koumbi, L, Andrikopoulos NK. Invitro gastric cancer prevention by a polyphenol-rich extract from olives through induction of apoptosis. Eur J Cancer Prev 2009; 18 : 33-9.

[200] Mouria M, Gukovskaya A, Jung Y, Buechler P, Hines O, Reber H. Food-derived polyphenols inhibit pancreatic cancer growth through mitochondrial cytochrome $\mathrm{c}$ release and apoptosis. Int $\mathbf{J}$ Cancer 2002; 98: 761-69.

[201] Ramos S, Alia M, Bravo L, Goya L. Comparative effects of foodderived polyphenols on the viability and apoptosis of a human hepatoma cell line (HepG2). J Agric Food Chem 2005; 53: 127180

[202] Galati G, Teng S, Moridani MY, Chang TS, O’Brien PJ. Cancer chemoprevention and apoptosis mechanisms induced by dietary polyphenols. Drug Metab Drug Interact 2000; 17: 311-49.

[203] Hudson TS, Hartle DK, Hursting SD, Nunez NP, Wang TT, Young $\mathrm{HA}$, et al. Inhibition of prostate cancer growth by muscadine grape skin extract and resveratrol through distinct mechanisms. Cancer Res 2007; 67: 8396-8405.

[204] Kaur M, Singh RP, Gu M, Agarwal R, Agarwal C. Grape seed extract inhibits in vitro and in vivo growth of human colorectal carcinoma cells. Clin. Cancer Res 2006; 12: 6194-202.

[205] Kaur M, Agarwal R, Agarwal C. Grape seed extract induces anoikis and caspase-mediated apoptosis in human prostate carcinoma LNCaP cells: Possible role of ataxia telangiectasia mutated-p53 activation. Mol Cancer Ther 2006; 5: 1265-1274.

[206] Kim MJ, Kim YJ, Park HJ, Chung JH, Leem KH, Kim HK. Apoptotic effect of red wine polyphenols on human colon cancer SNU-C4 cells. Food Chem Toxicol 2006; 44: 898-902.

[207] Raina K, Singh, RP, Agarwal R, Agarwal C. Oral grape seed extract inhibits prostate tumor growth and progression in TRAMP mice. Cancer Res 2007; 67: 5976-82.

[208] Tedesco I, Nappo A, Petitto F, Iacomino G, Nazzaro F, Palumbo R, et al. Antioxidant and cytotoxic properties of lyophilized beer extracts on HL-60 cell line. Nutr Cancer 2005; 52: 74-83.

[209] Seeram NP, Adams LS, Zhang Y, Lee R, Sand D, Scheuller HS, et al. Blackberry, black raspberry, blueberry, cranberry, red raspberry, and strawberry extracts inhibit growth and stimulate apoptosis of human cancer cells in vitro. J Agric. Food Chem 2006; 54: 9329-39.

[210] Malik A, Afaq F, Sarfaraz S, Adhami VM, Syed DN, Mukhtar H. Pomegranate fruit juice for chemoprevention and chemotherapy of prostate cancer. Proc Natl Acad Sci USA 2005; 102: 14813-8.

[211] Fujii T, Ikami T, Xu JW, Ikeda K. Prune extract (Prunus domestica L.) suppresses the proliferation and induces the apoptosis of human colon carcinoma caco-2. J Nutr Sci Vitaminol (Tokyo) 2006; 52: 389-91.

[212] Ding H, Chin YW, Kinghorn AD, D'Ambrosio SM. Chemopreventive characteristics of avocado fruit. Semin Cancer Biol 2007; 17: 386-94.

[213] Saha P, Banerjee S, Ganguly C, Manna S, Panda CK, Das S. Black tea extract can modulate protein expression of H-ras, c-Myc, p53, and Bcl-2 genes during pulmonary hyperplasia, dysplasia, and carcinoma in situ. J Environ Pathol Toxicol Oncol 2005; 24: 211 24.

[214] Bhattacharyya A, Lahiry L, Mandal D, Sa G, Das T. Black tea induces tumor cell apoptosis by Bax translocation, loss in mitochondrial transmembrane potential, cytochrome c release and caspase activation. Int J Cancer 2005; 117: 308-15.
[215] Srivastava JK, Gupta S. Antiproliferative and apoptotic effects of chamomile extract in various human cancer cells. J Agric Food Chem 2007; 55: 9470-8.

[216] Conney AH, Zhou S, Lee MJ, Xie JG, Yang CS, Lou YR, et al. Stimulatory effect of oral administration of tea, coffee or caffeine on UVB-induced apoptosis in the epidermis of SKH-1 mice. Toxicol Appl Pharmacol 2007; 224: 209-13.

[217] Scifo C, Milasi A, Guarnera A., Sinatra F, Renis M. Resveratrol and propolis extract: An insight into the morphological and molecular changes induced in DU145 cells. Oncol Res 2006; 15: 409-21.

[218] Cai H, Hudson EA, Mann P, Verschoyle RD, Greaves P, Manson $\mathrm{MM}$, et al. Growth-inhibitory and cell cycle-arresting properties of the rice bran constituent tricin in human-derived breast cancer cells in vitro and in nude mice in vivo. Br J Cancer 2004; 91: 1364-71.

[219] Vijaya Padma V, Arul Diana Christie S, Ramkuma KM. Induction of apoptosis by ginger in HEp-2 cell line is mediated by reactive oxygen species. Basic Clin Pharmacol Toxicol 2007; 100: 302-7.

[220] Sebastian KS, Thampan RV. Differential effects of soybean and fenugreek extracts on the growth of MCF-7 cells. Chem Biol Interact 2007; 170: 135-43

[221] Juan ME, Wenzel U, Ruiz-Gutierrez V, Daniel H, Planas JM. Olive fruit extracts inhibit proliferation and induce apoptosis in HT-29 human colon cancer cells. J Nutr 2006; 136: 2553-7.

[222] Fabiani R, De Bartolomeo A, Rosignoli P, Servili M, Selvaggini R, Montedoro GF, et al. Virgin olive oil phenols inhibit proliferation of human promyelocytic leukemia cells (HL60) by inducing apoptosis and differentiation. J Nutr 2006; 136: 614-9.

[223] Sacco SM, Power KA, Chen J, Ward WE, Thompson LU. Interaction of sesame seed and tamoxifen on tumor growth and bone health in athymic mice. Exp Biol Med 2007; 232: 754-61.

[224] Reddivari L, Vanamala J, Chintharlapalli S, Safe SH, Miller Jr JC. Anthocyanin fraction from potato extracts is cytotoxic to prostate cancer cells through activation of caspase-dependent and caspaseindependent pathways. Carcinogenesis 2007; 28: 2227-2235.

[225] Sarkar FH, Li Y. Using chemopreventive agents to enhance the efficacy of cancer therapy. Cancer Res 2006; 66: 3347-50.

[226] Chan M, Fong D, Soprano K, Holmes W, Heverling H. Inhibition of growth and sensitization to cisplatin-mediated killing of ovarian cancer cells by polyphenolic chemopreventive agents. J Cell Physiol 2003; 194: 63-70.

[227] Khafif, A, Schantz, S, Chou, T, Edelstein, D, Sacks, P. Quantitation of chemopreventive synergism between (-)-epigallocatechin-3gallate and curcumin in normal, premalignant and malignant human oral epithelial cells. Carcinogenesis 1998; 19: 419-24.

[228] Mertens-Talcott S, Percival S. Ellagic acid and quercetin interact synergistically with resveratrol in the induction of apoptosis and cause transient cell cycle arrest in human leukemia cells. Cancer Lett 2005; 218: 141-51.

[229] Suganuma M, Okabe S, Kai Y, Sueoka N, Sueoka E, Fujiki H. Synergistic effects of (--)-epigallocatechin gallate with (--) epicatechin, sulindac, or tamoxifen on cancer-preventive activity in the human lung cancer cell line PC-9. Cancer Res 1999: 59, 44-7.

[230] Sharma H, Sen S, Singh N. Molecular pathways in the chemosensitization of cisplatin by quercetin in human head and neck cancer Cancer Biol Ther 2005; 4: 949-55.

[231] Jakubowicz-Gil J, Paduch R, Piersiak T, Glowniak K, Gawron A, Kandefer-Szerszen M. The effect of quercetin on pro-apoptotic activity of cisplatin in HeLa cells. Biochem Pharmacol 2003; 69: 1343-50.

[232] Hwang JT, Ha J, Park O. Combination of 5-fluorouracil and genistein induces apoptosis synergistically in chemo-resistant cancer cells through the modulation of AMPK and COX-2 signaling pathways. Biochem Biophys Res Commun 2005; 332: 433-40.

[233] Pezzuto JM. Plant-derived anticancer agents. Biochem Pharmacol 1997; 53: 121-33.

[234] Passi S, Picardo M, Nazarro-Porro M. Comparative cytotoxicity of phenols in vitro. Biochem J 1987; 245: 537-42.

[235] Moridani MY, Galati G, O’Brien PJ. Comparative quantitative structure toxicity relationships for flavonoids evaluated in isolated rat hepatocytes and HeLa tumor cells. Chem Biol Interact 2002; 139: 251-64.

[236] Siraki A, Chan TS, O’Brien PJ. Application of quantitative structure-toxicity relationships for the comparison of the 
cytotoxicity of 14 p-benzoquinone congeners in primary cultured rat hepatocytes versus PC12 cells. Toxicol Sci 2004; 81: 148-59.

[237] Depeint F, Gee JM, Williamson G, Johnson IT. Evidence for consistent patterns between flavonoid structures and cellular activities. Proc Nutr Soc 2002; 61: 97-103.

[238] Gomes CA, Girão da Cruz, T, Andrade JL, Milhazes N, Borges F, Marques MPM. Anticancer activity of phenolic acids of natural or synthetic origin: a structure-activity study. J Med Chem 2003; 46: 5395-401.

[239] van Besien E, Marques MPM. Ab initio conformational study of caffeic acid. J Molec Struct (THEOCHEM) 2003; 625: 265-75.

[240] Fiuza, S.M, Van Besien, E, Milhazes, N, Borges, F, Marques, MPM. Conformational analysis of a trihydroxylated derivative of cinnamic acid-a combined Raman spectroscopy and Ab initio study. J Mol Struct 2004; 693:103-18.

[241] Calheiros, R, Milhazes, N, Borges, F, Marques, MPM. $\beta$ Nitrostyrene derivatives - a conformational study by combined Raman spectroscopy and ab initio MO calculations. J Mol Struct 2004; 692: 91-106.

[242] Fiuza SM, Gomes C, Teixeira LJ. Girão da Cruz MT. Cordeiro MN, Milhazes $\mathrm{N}$, et al. Phenolic acid derivatives with potential anticancer properties--a structure-activity relationship study. Part 1: methyl, propyl and octyl esters of caffeic and gallic acids. Bioorg Med Chem 2004; 12: 3581-9.

[243] Teixeira S, Siquet C, Alves C, Boal I, Marques MPM, Borges F, et al. Structure-property studies on the antioxidant activity of flavonoids present in diet. Free Radic Biol Med 2005; 39: 1099108.

[244] Milhazes N, Calheiros R, Marques MPM, Garrido J, Cordeiro MNDS, Rodrigues $\mathrm{C}$, et al. Beta-nitrostyrene derivatives as potential antibacterial agents: a structure-property-activity relationship study. Bioorg Med Chem 2006; 14: 4078-88.

[245] Rice-Evans CA, Miller NJ, Paganga G. Structure-antioxidant activity relationships of flavonoids and phenolic acids. Free Radic Biol Med 1996; 20: 933-56.

[246] Phan TT, Wang L, Grayer RJ, Chan SY, Lee ST. Phenolic compounds of Chromolaena odorata protect cultured skin cells from oxidative damage: implication for cutaneous wound healing. Biol Pharm Bull 2001; 24: 1373-9.

[247] Esteves M, Siquet C, Gaspar A, Rio V, Sousa J, Reis S, et al. Antioxidant versus cytotoxic properties of hydroxycinnamic acid derivatives - a new paradigm in phenolic research. Arch Pharm 2008; 341: 64-73.

[248] Aruoma O, Murcia A, Butler J, Halliwell B. Evaluation of the antioxidant and prooxidant actions of gallic acid and its derivatives. J Agric Food Chem 1993; 41: 1880-5.

[249] Li Y, Trush M. Reactive oxygen-dependent DNA damage resulting from the oxidation of phenolic compounds by a copper-redox cycle mechanism. Cancer Res 1994; 54: 1895-8.

[250] Cao G, Sofic E, Prior RL. Antioxidant and prooxidant behavior of flavonoids: structure-activity relationships. Free Radic Biol Med 1997; 22: 749-60.

[251] Galati G, Sabzevari O, Wilson JX, O’Brien PJ. Prooxidant activity and cellular effects of the phenoxyl radicals of dietary flavonoids and other polyphenolics. Toxicology 2002; 177: 91-104.

[252] Khan NS, Ahmad A, Hadi SM. Anti-oxidant, pro-oxidant properties of tannic acid and its binding to DNA. Chemicobiol Interact 2000; 125: 177-189.

[253] Serini S, Piccioni E, Merendino N, Calviello G. Dietary polyunsaturated fatty acids as inducers of apoptosis: implications for cancer. Apoptosis 2009; 14: 135-52.

[254] Herman-Antosiewicz A, Singh S. Signal transduction pathways leading to cell arrest and apoptosis induction in cancer cells by Allium vegetable-derived organosulfur compounds: a review. Mutat Res 2004; 555: 121-31.

[255] Palozza P. Sestito R, Picci N, Lanza P, Monego G, Ranelletti FO. The sensitivity of -carotene growth-inhibitory and pro-apoptotic effects is regulated by caveolin-1 expression in human colon and prostate cancer cells. Carcinogenesis 2008; 11: 2153-61.

[256] Constantinou C, Papas A, Constantinou I. Vitamin E and cancer: An insight into the anticancer activities of vitamin $\mathrm{E}$ isomers and analogs. Int J Cancer 2008; 123:739-52.

[257] Guan L, Han B, Li Z, Fangyuan H, Huang F, Wei W, et al. Sodium selenite induces apoptosis by ROS-mediated endoplasmic reticulum stress and mitochondrial dysfunction in human acute promyelocytic leukemia NB4 cells. Apoptosis 2009; 14: 218-25.
[258] Hong S-W, Jin D-H, Hahm E-S, Yim S-H, Lim J-S, Kim K-I, et al. Ascorbate (vitamin $\mathrm{C}$ ) induces cell death through the apoptosisinducig factor in human breast cancer cells. Mutat Res 2004; 555: 121-31.

[259] Hwang ES, Bowen PE. Cell cycle arrest and induction of apoptosis by lycopene in LNCaP human prostate cancer cells. J Med Food 2004; 7: 284-289.

[260] Kim HS, Bowen P, Chen L, Duncan C, Ghosh L, Sharifi R, et al. Effects of tomato sauce consumption on apoptotic cell death in prostate benign hyperplasia and carcinoma. Nutr Cancer 2003; 47: 40-7.

[261] Borek C. Dietary antioxidants and human cancer. Integr Cancer Ther 2004; 3: 333-41.

[262] Fields AL, Soprano DR, Soprano KJ. Retinoids in biological control and cancer. J Cell Biochem 2007; 102: 886-98.

[263] Gosslau A, Chen KY. Nutraceuticals, apoptosis, and disease prevention. Nutrition 2004; 20: 95-102.

[264] Cheung E, Wadhera P, Dorff T, Pinski J. Diet and prostate cancer risk reduction. Expert Rev Anticancer Ther 2008; 8:43-50.

[265] Velmurugan B, Mani A, Nagini S. Combination of S-allylcysteine and lycopene induces apoptosis by modulating Bcl-2, Bax, Bim and caspases during experimental gastric carcinogenesis. Eur J Cancer Prev 2005; 14: 387-93.

[266] Fimognari C, Nüsse M, Berti F, Iori R, Cantelli-Forti G, Hrelia P. Isothiocyanates as novel cytotoxic and cytostatic agents: molecular pathway on human transformed and non-transformed cells Biochem Pharmacol 2004; 15: 1133-8.

[267] Fimognari C, Hrelia P. Sulforaphane as a promising molecule for fighting cancer. Mutat Res 2007; 635: 90-104

[268] Gingras D, Gendron M, Boivin D, Moghrabi A, Théorêt Y, Béliveau R. Induction of medulloblastoma cell apoptosis by sulforaphane, a dietary anticarcinogen from Brassica vegetables. Cancer Lett 2004; 203: 35-43.

[269] Moiseeva EP, Almeida GM, Jones GD, Manson MM. Extended treatment with physiologic concentrations of dietary phytochemicals results in altered gene expression, reduced growth, and apoptosis of cancer cells. Mol Cancer Ther 2007; 6: 3071-9.

[270] Mezencev R, Mojzis J, Pilátová M, Kutschy P. Antiproliferative and cancer chemopreventive activity of phytoalexins: Focus on indole phytoalexins from crucifers. Neoplasma 2003; 50: 239-45.

[271] Rogan EG. The natural chemopreventive compound indole-3 carbinol: State of the science. In Vivo 2006; 20: 221-8.

[272] Neuzil J, Dong LF, Ramanathapuram L, Hahn T, Chladova M, Wang XF, et al. Vitamin E analogues as a novel group of mitocans: anti-cancer agents that act by targeting mitochondria. Mol Aspects Med 2007; 28: 607-45.

[273] Nesaretnam K, Wong WY, Wahid MB. Alpha-tocopheryl phosphate is a novel apoptotic agent. Eur J Lipid Sci Technol 2007; 109: 445-52.

[274] Ogawa M, Nakai S, Deguchi A, Nonomura T, Masaki T, Uchida N, et al. Vitamins $\mathrm{K} 2, \mathrm{~K} 3$ and $\mathrm{K} 5$ exert antitumor effects on established colorectal cancer in mice by inducing apoptotic death of tumor cells. Int J Oncol 2007; 31: 323-31.

[275] Rooprai HK, Kyriazis I, Nuttall RK, Edwards DR, Zicha D, Aubyn $\mathrm{D}$, et al. Inhibition of invasion and induction of apoptosis by selenium in human malignant brain tumour cells in vitro. Int $\mathbf{J}$ Oncol 2007; 30: 1263-71.

[276] Keck AS, Finley JW. Cruciferous Vegetables: Cancer Protective Mechanisms of Glucosinolate Hydrolysis Products and Selenium. Integr Cancer Ther 2004; 3: 5-12.

[277] Aboul-Fadl T. Selenium derivatives as cancer preventive agents Curr Med Chem Anticancer Agents 2005; 5: 637-52.

[278] Young GP, Hu Y, Le Leu RK, Nyskohus L. Dietary fibre and colorectal cancer: A model for environment - Gene interactions. Mol Nutr Food Res 2005; 49: 571-84.

[279] Edris AE. Pharmaceutical and therapeutic potentials of essential oils and their individual volatile constituents: a review. Phytother Res 2007; 21: 308-323.

[280] Dudai N, Weinstein Y, Krup M, Rabinski T, Ofir R. Citral is a new inducer of caspase-3 in tumor cell lines. Planta Med 2005; 71: 4848

[281] Raghuvar Gopal DV, Narkar AA, Badrinath Y, Mishra KP, Joshi DS. Betulinic acid induces apoptosis in human chronic myelogenous leukemia (CML) cell line K-562 without altering the levels of Bcr-Abl. Toxicol Lett 2005; 155: 343-51. 
[282] Yeruva L, Pierre KJ, Elegbede A, Wang RC, Carper SW. Perillyl alcohol and perillic acid induced cell cycle arrest and apoptosis in non small cell lung cancer cells. Cancer Lett 2007; 257: 216-226.

[283] Harmand PO, Duval R, Delage C, Simon A. Ursolic acid induces apoptosis through mitochondrial intrinsic pathway and caspase-3 activation in M4Beu melanoma cells. Int J Cancer 2005; 114: 1-11.

[284] Shidoji Y, Ogawa H. Natural occurrence of cancer-preventive geranylgeranoic acid in medicinal herbs. J Lipid Res 2004; 45: 1092-1103.

[285] Joo JH, Liao G, Collins JB, Grissom SF, Jetten AM. Farnesolinduced apoptosis in human lung carcinoma cells is coupled to the endoplasmic reticulum stress response. Cancer Res 2007; 67: 792936.

[286] Bode AM, Dong Z. The enigmatic effects of caffeine in cell cycle and cancer. Cancer Lett 2007; 247: 26-39.

[287] Malki AM, Gentry J, Evans SC. Differential effect of selected methylxanthine derivatives on radiosensitization of lung carcinoma cells. Exp Oncol 2006, 28, 16-24.

[288] Shiu LY, Chang LC, Liang CH, Huang YS, Sheu HM, Kuo KW. Solamargine induces apoptosis and sensitizes breast cancer cells to cisplatin. Food Chem Toxicol 2007; 45: 2155-64.

[289] Zhu T, Guo J, Collins L, Kelly J, Xiao ZJ, Kim SH, et al. Phellinus linteus activates different pathways to induce apoptosis in prostate cancer cells. Br J Cancer 2007; 96: 583-90.

[290] Lavi I, Friesem D, Geresh S, Hadar Y, Schwartz B. Cell-cycle arrest and apoptosis induction in human breast carcinoma MCF-7 cells by carboxymethylated $\beta$-glucan from the mushroom sclerotia of Pleurotus tuber-regium. Cancer Lett 2006; 244: 61-70.

[291] Lavi I, Friesem D, Geresh S, Hadar Y, Schwartz B. An aqueous polysaccharide extract from the edible mushroom Pleurotus ostreatus induces anti-proliferative and pro-apoptotic effects on HT29 colon cancer cells. Carbohydr Polymer 2006; 66: 455-62.

[292] Hasegawa M, Yagi K, Iwakawa S, Hirai M. Chitosan induces apoptosis via caspase-3 activation in bladder tumor cells. Jpn J Cancer Res 2001; 92:459-466.

[293] Calviello G, Serini S, Piccioni E. Omega-3 polyunsaturated fatty acids and the prevention of colorectal cancer: molecular mechanisms involved. Curr Med Chem 2007; 14: 3059-69.

[294] Narayan B, Hosokawa M, Yasui Y, Suzuki R, Kohno H, Tanaka T, Miyashita K. Chemopreventive effects of conjugated linolenic acids (CLN) occurring in plant seed oils. Curr Nutr Food Sci 2007; 3: 309-18.
[295] Kato T, Kolenic N, Pardini RS. Docosahexaenoic Acid (DHA), a primary tumor suppressive omega-3 fatty acid, inhibits growth of colorectal cancer independent of p53 mutational status. Nutr Cancer 2007; 58: 178-87.

[296] Courtney ED, Matthews S, Finlayson C, Pierro D, Belluzzi A, Roda $\mathrm{E}$, et al. Eicosapentaenoic acid (EPA) reduces crypt cell proliferation and increases apoptosis in normal colonic mucosa in subjects with a history of colorectal adenomas. Int J Colorectal Dis 2007; 22: 765-76.

[297] Parodi PW. A role for milk proteins and their peptides in cancer prevention. Curr Pharm Des 2007; 13: 813-28.

[298] Mohan KV, Gunasekaran P, Varalakshmi E, Hara Y, Nagini S. In vitro evaluation of the anticancer effect of lactoferrin and tea polyphenol combination on oral carcinoma cells. Cell Biol Int 2007; 31: 599-608.

[299] Reed JC. Apoptosis-regulating proteins as targets for drug discovery. Trends Mol Med 2001; 7: 314-9.

[300] Willett WC. Diet, nutrition, and avoidable cancer. Environ Health Perspect 1995; 103: 165-70.

[301] Zhou B, Zhong-Li L. Bioantioxidants: From chemistry to biology. Pure Appl Chem 2005; 77: 1887-1903.

[302] Manson MM, Farmer PB, Gescher A, Steward WP. Innovative agents in cancer prevention. Recent Results Cancer Res 2005; 166: 257-75.

[303] Aruoma OI. Nutrition and health aspects of free radicals and antioxidants. Chem Toxicol 1994; 32: 671-83.

[304] Hercberg S. The history of beta-carotene and cancers: from observational to intervention studies. What lessons can be drawn for future research on polyphenols? Am J Clin Nutr 2005; 81: 223S-9S

[305] Magrone T, Candore G, Caruso C, Jirillo E, Covelli V. Polyphenols from red wine modulate immune responsiveness: biological and clinical significance. Curr Pharm Des 2008; 14(26): 2733-48.

[306] Magrone T, Panaro MA, Jirillo E, Covelli V. Molecular effects elicited in vitro by red wine on human healthy peripheral blood mononuclear cells: potential therapeutical application of polyphenols to diet-related chronic diseases. Curr Pharm Des 2008; 14(26): 2758-66.

[307] Magrone T, Tafaro A, Jirillo F, Amati L, Jirillo E, Covelli V. Elicitation of immune responsiveness against antigenic challenge in age-related diseases: effects of red wine polyphenols. Curr Pharm Des 2008; 14(26): 2749-57. 